\title{
Methanol Reforming Processes for Fuel Cell Applications
}

\author{
Konstantinos Kappis ${ }^{1}$, Joan Papavasiliou ${ }^{1,2, *}$ and George Avgouropoulos $1, *$ (D) \\ 1 Department of Materials Science, University of Patras, GR-26504 Patras, Greece; k.kappis@upatras.gr \\ 2 Foundation for Research and Technology-Hellas (FORTH), Institute of Chemical Engineering \\ Sciences (ICE-HT), P.O. Box 1414, GR-26504 Patras, Greece \\ * Correspondence: ipapavas@upatras.gr (J.P.); geoavg@upatras.gr (G.A.); Tel.: +30-261-099-6361 (J.P.); \\ $+30-261-099-6312$ (G.A.)
}

check for

updates

Citation: Kappis, K.; Papavasiliou, J.; Avgouropoulos, G. Methanol Reforming Processes for Fuel Cell Applications. Energies 2021, 14, 8442. https://doi.org/10.3390/en14248442

Academic Editor: Attilio Converti

Received: 1 November 2021

Accepted: 10 December 2021

Published: 14 December 2021

Publisher's Note: MDPI stays neutral with regard to jurisdictional claims in published maps and institutional affiliations.

Copyright: (c) 2021 by the authors. Licensee MDPI, Basel, Switzerland. This article is an open access article distributed under the terms and conditions of the Creative Commons Attribution (CC BY) license (https:/ / creativecommons.org/licenses/by/ $4.0 /)$.

\begin{abstract}
Hydrogen production through methanol reforming processes has been stimulated over the years due to increasing interest in fuel cell technology and clean energy production. Among different types of methanol reforming, the steam reforming of methanol has attracted great interest as reformate gas stream where high concentration of hydrogen is produced with a negligible amount of carbon monoxide. In this review, recent progress of the main reforming processes of methanol towards hydrogen production is summarized. Different catalytic systems are reviewed for the steam reforming of methanol: mainly copper- and group 8-10-based catalysts, highlighting the catalytic key properties, while the promoting effect of the latter group in copper activity and selectivity is also discussed. The effect of different preparation methods, different promoters/stabilizers, and the formation mechanism is analyzed. Moreover, the integration of methanol steam reforming process and the high temperature-polymer electrolyte membrane fuel cells (HT-PEMFCs) for the development of clean energy production is discussed.
\end{abstract}

Keywords: steam reforming of methanol; copper catalysts; hydrogen production; fuel cells; HT-PEMFCs

\section{Introduction}

In a world where the human population is exponentially expanded and economic growth is highly desired, it is of paramount need to secure and utilize adequate energy resources [1]. However, the high reliance on fossil fuels in order to achieve the above goal has caused detrimental effects on the environment, mainly due to greenhouse gas emissions [2,3]. Therefore, transforming the current status of energy generation into a greener way, not only will allow greenhouse gas emissions to be stabilized and/or reduced, but will also promote the sustainability of the society [4]. Hydrogen $\left(\mathrm{H}_{2}\right)$ is considered as the clean fuel of the future, especially when it is produced from water electrolysis supported by solar or/and wind energy (renewable or green hydrogen), and there are huge efforts around the world to implement hydrogen roadmaps towards decarbonization of industry, transport, power, and buildings sectors and climate neutrality by 2050. Its attractive features both as a feedstock and fuel or energy carrier and storage medium, offer a viable solution for a sustainable future society. All this makes hydrogen essential to support the EU's commitment to reach carbon neutrality by 2050 and for the global effort to implement the Paris Agreement while working towards zero pollution [5].

Fuel cells and especially, polymer electrolyte membrane fuel cells (PEMFCs) are considered a clean and efficient technology, covering a wide range of portable and stationary applications [6,7]. This type of fuel cells is divided into two categories according to the temperature level of operation: low-temperature PEMFCs (around $60-80{ }^{\circ} \mathrm{C}$ ) and hightemperature PEMFCs (around 160-220 ${ }^{\circ} \mathrm{C}$ ) [8]. Each class demonstrates its own benefits, with HT-PEMFCs having extraordinary advantages compared with the low-temperature counterparts. It has to be noted that the increase in the operational temperature can lead 
to higher tolerance in carbon monoxide (CO) and better confrontation in water management system $[9,10]$. Typically, $\mathrm{H}_{2}$ is used as an energy carrier in PEMFCs, leading to high energy efficiency and negligible emissions [11,12]. However, the further application of $\mathrm{H}_{2}$ is limited due to the complex installation of a refueling unit and the difficulties associated with on-board storage and handling [13-15]. The aforementioned limitations in fuel cell systems can be overcome through a technology known as fuel processing. In this technology, alternative fuels such as methane, methanol, ethanol, and dimethyl ether can be converted to a hydrogen-rich gas (reformate) in order to feed the fuel cells [16,17]. Methanol is considered as one of the most favorable fuels for producing hydrogen on board, due to several advantages. It presents high hydrogen to carbon ratio $(\mathrm{H} / \mathrm{C}=4 / 1)$, and thus a $\mathrm{H}_{2}$-rich gas stream upon reforming can be extracted. The liquid form of methanol at ambient conditions and its high miscibility with water enable the easiest containment and transportation $[18,19]$. The conversion of methanol to a hydrogen-rich reformate can occur in a lower temperature range $\left(200-350{ }^{\circ} \mathrm{C}\right.$ ) with regard to methane (above $500{ }^{\circ} \mathrm{C}$ ) and ethanol (around $400{ }^{\circ} \mathrm{C}$ ) due to the absence of C-C bonds [20-22]. Another advantage of methanol is that it can be produced by many sources, such as methane, oil, coal, and renewable sources, for instance, biomass, and renewable electricity [23-26]. In this way, methanol can play a significant role in a transition period towards decarbonization of various energy activities by 2050. Moreover, if it is accompanied with carbon dioxide $\left(\mathrm{CO}_{2}\right)$ capture/storage/utilization technologies (blue hydrogen), it can be considered as a renewable energy solution with zero carbon footprint.

There are several ways for producing hydrogen from methanol, namely, methanol decomposition (MD), partial oxidation of methanol (POM), steam reforming of methanol (SRM), and oxidative steam reforming of methanol (OSRM) [27-30]. The SRM reaction is proposed as the most attractive way of producing hydrogen as the latter is obtained at the highest concentration (up to 75\%) in the product stream [31,32]. Moreover, the reaction takes place at relatively low temperatures $\left(180-300{ }^{\circ} \mathrm{C}\right)$, producing a negligible amount of $\mathrm{CO}$, which acts as a poison for the anode catalyst of PEMFCs $[15,33,34]$.

The development of efficient catalytic systems is of paramount importance for the methanol steam reforming reaction. High activity (hydrogen with high yield), high selectivity (minimum CO concentrations), and high stability are considered desirable characteristics for an efficient SRM catalyst $[19,35]$. SRM catalysts are separated into two main categories: Cu-based catalysts [36,37] and group 8-10 catalysts [27,38]. Cu-based catalysts are commonly utilized for the SRM reaction due to their high activity and selectivity $[39,40]$. However, these catalysts suffer from deactivation due to their sintering, especially at high temperature, and pyrophoric behavior if exposed in air after use [41]. On the other hand, group 8-10 catalysts are highly stable in the temperature range of the reforming reaction [42]. Nevertheless, the amount of produced hydrogen is smaller than the copper-based counterparts, due to higher CO selectivities [18]. In order to promote the performance of both types of catalysts, several research approaches are reported; for example, the use of different promoters $[43,44]$ or the effect of preparation method $[45,46]$.

The integration of methanol steam reforming process with HT-PEMFCs is considered as an attractive arrangement especially for mobile or portable applications $[47,48]$. An important criterion for this coupling is the effective operation of the HT-PEMFCs in the same operational temperature range of SRM reaction. If similar operating temperatures between SRM process and the fuel cell are achieved, not only the balance-of-plant (BoP) will be simplified but also the energy efficiency of the system will increase [49,50]. One way to achieve the above criterion is the decrease in the optimum operating temperature of SRM reaction by developing a methanol reformer with high activity, selectivity, and stability [51,52].

In this review paper, the currents status of methanol reforming for fuel cell applications is summarized. At first, the main processes of methanol reforming for hydrogen production are discussed, emphasizing in the steam reforming of methanol. After that, the latest developments on the copper-based and group 8-10 catalysts for SRM reaction are reviewed. 
In the last section of this review, a brief discussion about the reformed methanol HTPEMFCs system is reported.

\section{Hydrogen Production through Methanol}

\subsection{Methanol Decomposition (MD)}

The decomposition of methanol is considered a simple and convenient reaction from a chemical point of view as the only feedstock is methanol [53-56].

$$
\mathrm{CH}_{3} \mathrm{OH} \rightarrow \mathrm{CO}+\mathrm{H}_{2} \quad \Delta \mathrm{H}^{0}=92.0 \mathrm{~kJ} / \mathrm{mol},
$$

The strong endothermicity of this reaction, as illustrated in Equation (1), requires a large amount of energy in order to proceed. Additionally, the composition of the resulted gas stream consists of $67 \%$ hydrogen and $33 \%$ carbon monoxide. In order for this reaction to be applicable in the fuel cell system, a CO purification unit is required as the former is highly poisonous for the anode compartment of low temperature PEMFCs [57]. The addition of a clean-up system for such high concentrations of $\mathrm{CO}$ adds a lot of complications, and thus the MD reaction is not considered suitable for PEMFCs applications.

\subsection{Partial Oxidation of Methanol (POM)}

The partial oxidation of methanol is an exothermic process (Equation (2)). Due to its exothermic nature, the supply of additional energy is not mandatory, as proposed in MD and SRM reactions $[28,58]$. Nevertheless, the high exothermicity makes difficult the temperature control inside the reactor, and thus the design of a suitable reactor should be taken into careful consideration. Specifically, hot spots can be formed by the rapid rise in the catalytic bed, triggering the deactivation of catalysts through sintering of the active phase.

$$
\mathrm{CH}_{3} \mathrm{OH}+\frac{1}{2} \mathrm{O}_{2} \rightarrow \mathrm{CO}_{2}+2 \mathrm{H}_{2} \quad \Delta \mathrm{H}^{0}=-192.2 \mathrm{~kJ} / \mathrm{mol}
$$

When pure oxygen is utilized in the feed, the methanol is partially oxidized to result in a gas product stream consisting of $67 \%$ hydrogen. However, it is suggested that for PEMFCs applications, the oxygen required for the POM reaction is going to be supplied from air. Several disadvantages in the operation of fuel cells can emerge due to this condition. The gas product stream can be diluted with nitrogen, decreasing the theoretical maximum hydrogen content to $41 \%$, and consequently the generation of electricity from fuel cells can be adversely affected [59].

\subsection{Steam Reforming of Methanol (SRM)}

The production of a hydrogen-rich gas stream can be proceeded through the chemical reaction between methanol and water vapor. This reaction is known as steam reforming of methanol (Equation (3)), and is the reverse reaction of methanol synthesis [31,60]. The SRM reaction can produce a gas reformate with high hydrogen content $(75 \%)$ and high selectivity for carbon dioxide.

$$
\mathrm{CH}_{3} \mathrm{OH}+\mathrm{H}_{2} \mathrm{O} \rightarrow \mathrm{CO}_{2}+3 \mathrm{H}_{2} \quad \Delta \mathrm{H}^{0}=49.4 \mathrm{~kJ} / \mathrm{mol},
$$

However, a set of side reactions takes place during the reforming process: the MD reaction (Equation (1)), the water-gas shift (WGS) and the reverse water-gas shift (rWGS) reactions (Equation (4)). The amount of produced $\mathrm{CO}$ is determined through these side reactions, with the rWGS reaction being of great importance since it is considered the primary reaction for $\mathrm{CO}$ production $[61,62]$.

$$
\mathrm{CO}+\mathrm{H}_{2} \mathrm{O} \leftrightarrow \mathrm{CO}_{2}+\mathrm{H}_{2} \quad \Delta \mathrm{H}^{0}=-41.4 \mathrm{~kJ} / \mathrm{mol},
$$


The performance on steam reforming of methanol can be affected by important parameters such as the reforming temperature $\left(\mathrm{T}_{\text {ref }}\right)$ and the steam to carbon ratio $(\mathrm{S} / \mathrm{C})$. The thermodynamic analysis of methanol reforming can shed light on the effects of the aforementioned parameters in order to find the optimal operating conditions of methanol steam reforming for fuel cell applications [61-64]. Faugnawakij et al. [61] performed a thermodynamic analysis of a SRM reaction for hydrogen production at various S/C ratios, temperatures, and pressures. According to their thermodynamic data, methanol can be fully converted at $200{ }^{\circ} \mathrm{C}$ for the stoichiometric S/C ratio (Figure 1), while the increase in the $\mathrm{S} / \mathrm{C}$ ratio can cause the complete methanol conversion at lower temperatures. On the other hand, for $\mathrm{S} / \mathrm{C}<1$, a steep decrease in methanol conversion for temperatures lower than $200{ }^{\circ} \mathrm{C}$ can be illustrated.

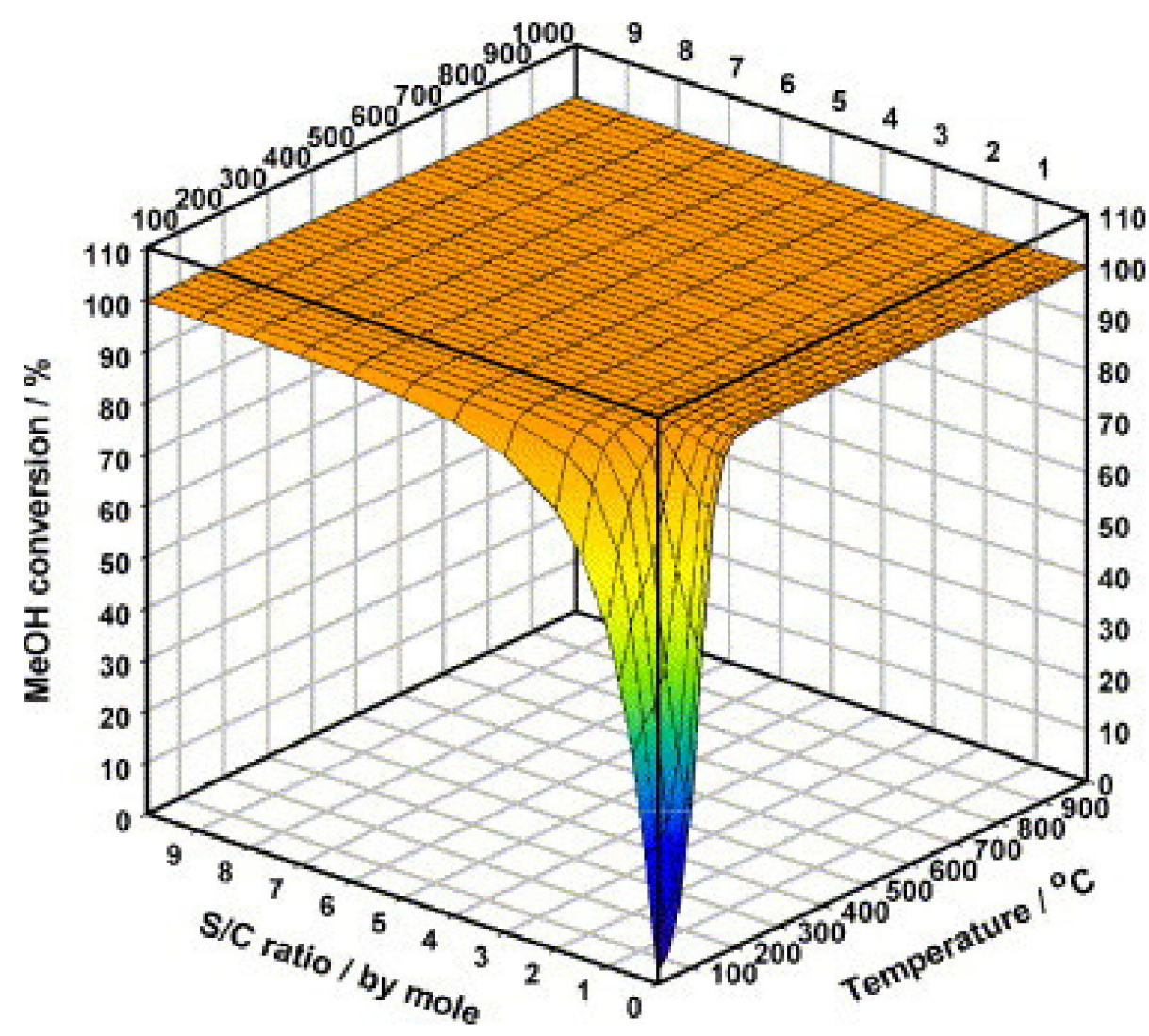

Figure 1. Equilibrium conversion of $\mathrm{MeOH}$ from SRM as a function of (S/C ratio and temperature. (Adapted from [61], copyright 2006, Elsevier.)

In terms of hydrogen production, the concentration of hydrogen on dry basis exceeds the percentage of $70 \%$ at $\mathrm{S} / \mathrm{C}=1$, and $\mathrm{T}_{\text {ref }}=200-500{ }^{\circ} \mathrm{C}$ (see Figure 2a). Interestingly, the concentration and the yield of hydrogen (see Figure $2 \mathrm{~b}$ ) can reach almost $75 \%$ and $100 \%$, respectively.

The high reforming efficiency (reformate with high concentration in hydrogen and low amount in $\mathrm{CO}$ ) can be achieved through optimizing the operating conditions at the temperature range $100-225^{\circ} \mathrm{C}, \mathrm{S} / \mathrm{C}=1.5-3$, and pressure at $1 \mathrm{~atm}$. Moreover, it is found that the conditions for low $\mathrm{CO}$ production (below $10 \mathrm{ppm}$ ) is harsh for existing catalytic systems. Furthermore, the methanol conversion and hydrogen yield are not affected by the variation of pressure.

Xing et al. [64] presented a similar thermodynamical analysis for SRM reaction utilizing the multifactor coupling method and the Gibbs free energy minimization method. Parameters of this study were the temperature, the $\mathrm{S} / \mathrm{C}$ ratio, the pressure, and the $\mathrm{H}_{2} / \mathrm{CO}$ ratio in the reformate gas stream. Regarding the coupling of temperature and $\mathrm{S} / \mathrm{C}$ ratio (Figure 3), it was found that increasing the temperature promotes the methanol conversion. 
However, this increase in temperature triggered the drop of hydrogen content in the reformate stream with the simultaneous rise of carbon monoxide concentration (Figure 4). The methanol conversion and hydrogen content could be improved though the increase in the $\mathrm{S} / \mathrm{C}$ ratio. In order for the SRM process to be integrated with HT-PEMFCs, the optimum values for the studied parameters are proposed as follows: $\mathrm{S} / \mathrm{C}=1.6-2.0$, temperature reforming range $200-300{ }^{\circ} \mathrm{C}$, and pressure at $1 \mathrm{~atm}$.

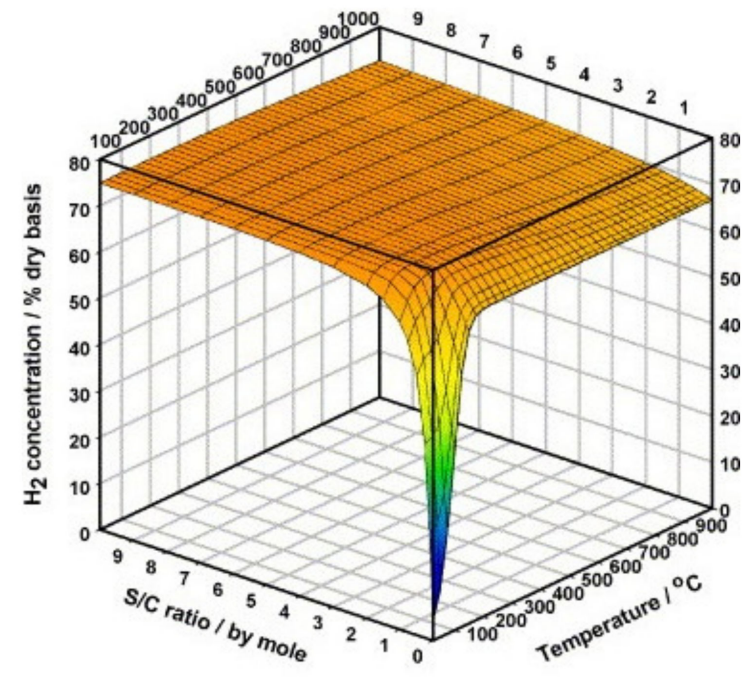

$\mathrm{H}_{2}$ conc. on a dry basis

(a)

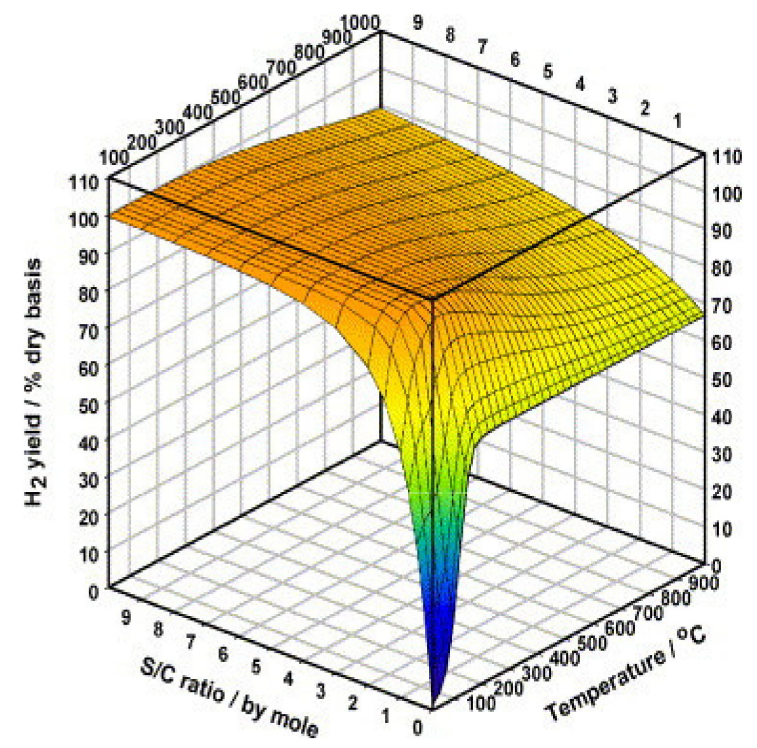

(b)

Figure 2. (a) Equilibrium hydrogen concentration on dry basis from SRM as a function of S/C ratio and temperature. (b) Equilibrium hydrogen yield from SRM as a function of S/C ratio and temperature. (Adapted from [61], copyright 2006, Elsevier.)

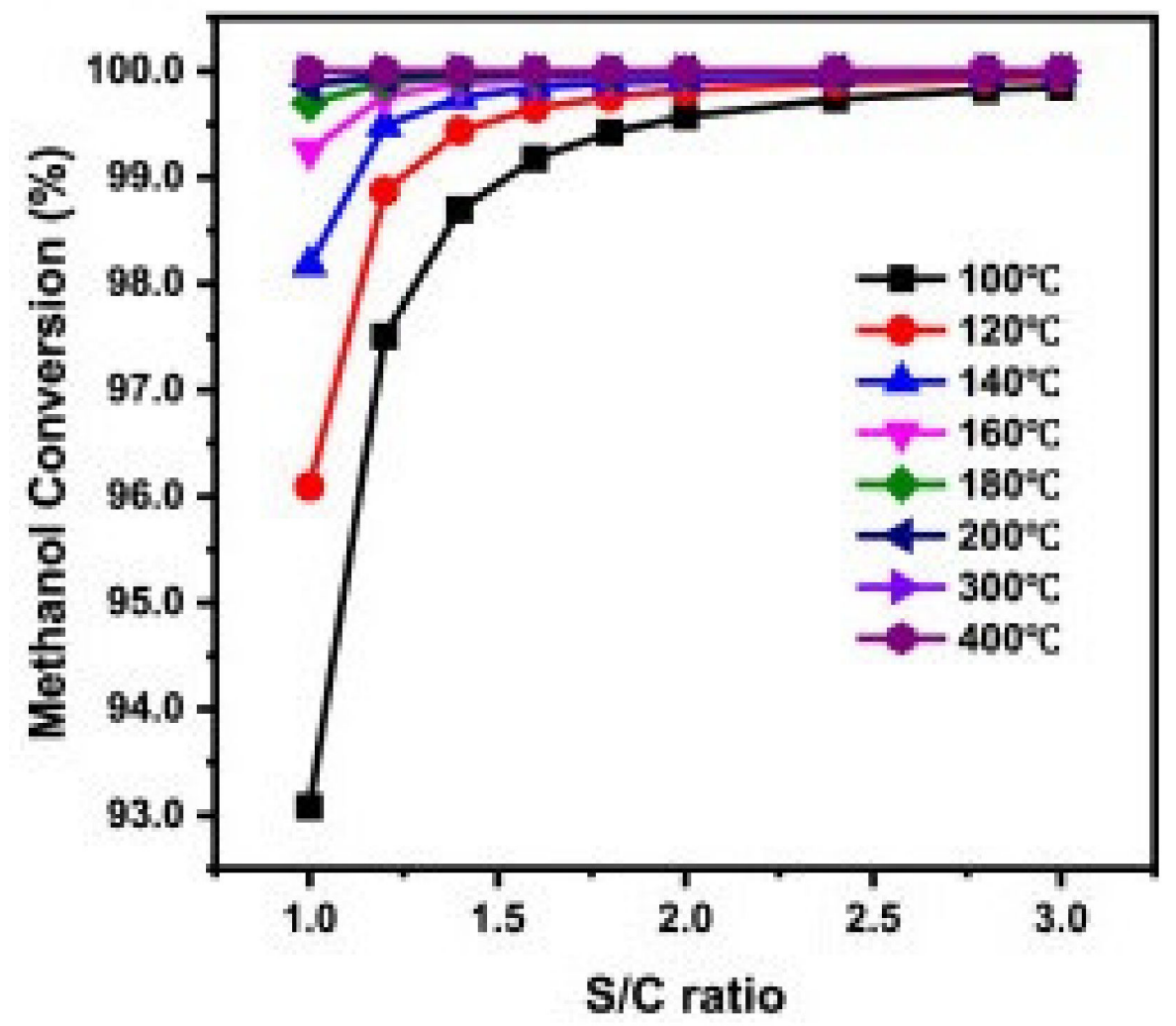

Figure 3. Effect of temperature and S/C ratio on methanol conversion. (Adapted from [64], copyright 2020, Elsevier.) 


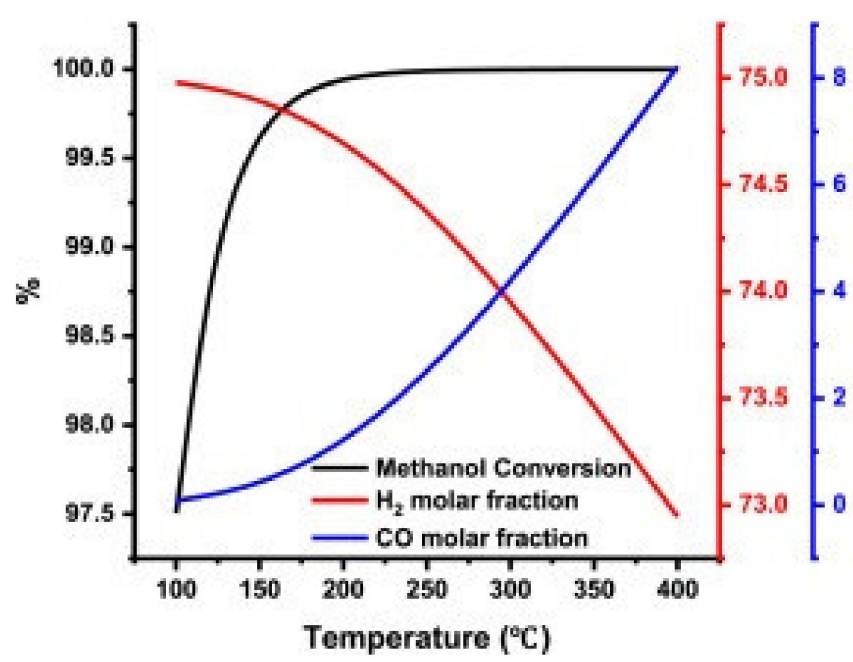

(a)

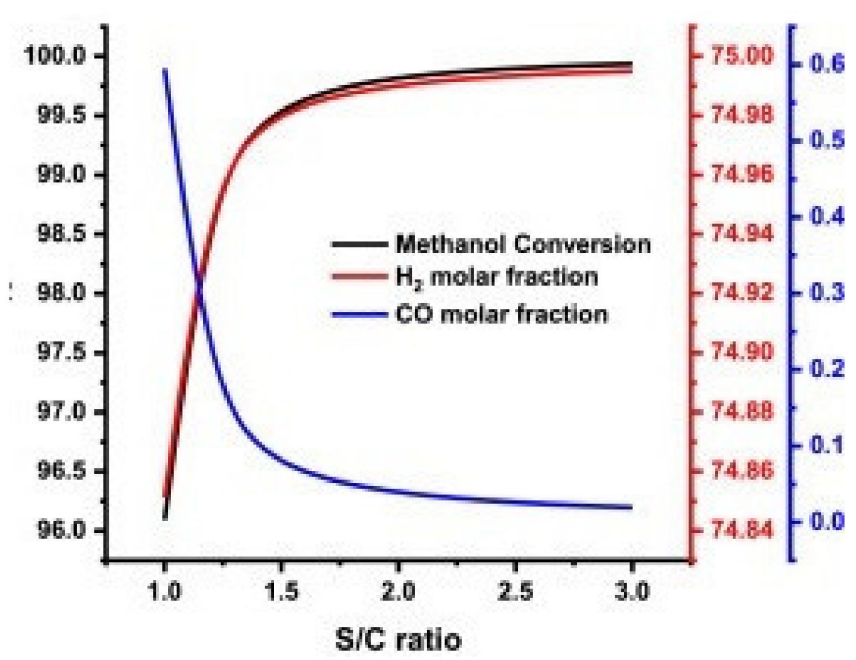

(b)

Figure 4. (a) Effect of temperature $\left(100-400^{\circ} \mathrm{C}\right)$ on SRM reaction system; pressure: $1.0 \mathrm{~atm}, \mathrm{~S} / \mathrm{C}$ ratio:1.2. (b) Effect of S/C ratio (1.0-3.0) on MSR reaction system; temperature: $120^{\circ} \mathrm{C}$, pressure:1.0 atm. (Adapted from [64], copyright 2020, Elsevier.)

To summarize the above results, it is of paramount importance to find the optimum operating conditions for methanol steam reforming. If this condition is met, then a hydrogen rich-gas stream will be produced, and a decrease in the concentration of poisonous $\mathrm{CO}$ will be also achieved.

\subsection{Oxidative Steam Reforming of Methanol (OSRM)}

The oxidative steam reforming of methanol (also known as autothermal reforming) is the combination of POM and SRM reactions. According to Equation (5), methanol reacts with both air and steam in order to produce a reformate stream with high concentration in hydrogen $[65,66]$.

$$
\mathrm{CH}_{3} \mathrm{OH}+(1-2 \mathrm{r}) \mathrm{H}_{2} \mathrm{O}+\mathrm{rO}_{2} \rightarrow \mathrm{CO}_{2}+(3-2 \mathrm{r}) \mathrm{H}_{2} \quad 0 \leq \mathrm{r} \leq 0.5,
$$

The ratio between oxygen and methanol supplied to the reaction is represented by the variable " $\mathrm{r}$ ". This variable can be adjusted in such way that the overall reaction can be thermo-neutral or slightly exothermic. This feature means that POM reaction can provide the necessary heat in order SRM reaction to be self-sustained and on the other hand, the violent exothermic behavior of POM to be controlled by the endothermic SRM reaction [67]. The reason behind the choice of a moderately exothermic behavior in the OSRM reaction is that the latter is not ideally balanced $\left(\Delta \mathrm{H}^{0}=0 \mathrm{~kJ} / \mathrm{mol}\right)$ and an amount of heat is released during the process [15]. The OSRM reaction exhibits faster startup and shutdown cycles as compared with POM reaction, also producing a hydrogen-rich gas stream. Nevertheless, the concentration of hydrogen in the reformate and the conversion of methanol are lower than that of the SRM reaction [68]. The most important characteristics of the aforementioned reforming processes are compared in Table 1.

Table 1. Typical characteristics of the referred reforming processes of methanol for hydrogen production.

\begin{tabular}{|c|c|c|c|c|c|c|}
\hline & & MD & POM & & SRM & OSRM \\
\hline $\mathrm{S} / \mathrm{C}$ ratio & & - & - & & $1.5-2.0$ & $1.2-1.5$ \\
\hline $\mathrm{O}_{2} / \mathrm{C}$ ratio & & - & $>0.5$ & & - & $0.10-0.25$ \\
\hline $\mathrm{H}_{2}$ produced (\%) & & 67.0 & 41.0 & & 75.0 & $55.0-60.0$ \\
\hline CO produced $(\%)$ & & 33.0 & $0.1-2.0$ & & $<1.0$ & 2.0 \\
\hline Remarks & 1. & Enormous amount of $\mathrm{CO}$ & Low amount of $\mathrm{H}_{2}$ & $\begin{array}{l}1 . \\
2 .\end{array}$ & $\begin{array}{l}\text { High concentration of } \mathrm{H}_{2} \\
\text { Most widely used }\end{array}$ & $\begin{array}{l}\text { 1. Ideally thermo-neutral } \\
\text { 2. Fast response rates }\end{array}$ \\
\hline
\end{tabular}




\section{Catalysts for Steam Reforming of Methanol}

\subsection{Cu-Based Catalysts}

Catalytic reactions in $\mathrm{C} 1$ chemistry are closely connected with copper-based catalysts. For instance, the most common industrial methanol synthesis catalyst is a complex $\mathrm{Cu} / \mathrm{ZnO} / \mathrm{Al}_{2} \mathrm{O}_{3}$ catalytic system The similarities between methanol synthesis and steam reforming of methanol reaction [69] make the $\mathrm{Cu} / \mathrm{ZnO}$ model system and an exceptional option for SRM reaction, as many of the requirements discussed above are fulfilled [19]. However, even if an optimization has already been made regarding the composition and preparation of the commercial copper-based catalyst for application in methanol synthesis, several improvements can be applied to the $\mathrm{Cu} / \mathrm{ZnO}$ binary catalytic system in order to improve the properties of latter for SRM reactions. The addition of different promoters/stabilizers, or the development/optimization of various preparation methods, can bring positive impact on the performance of $\mathrm{Cu}$-based catalysts.

\subsubsection{The $\mathrm{Cu} / \mathrm{ZnO}$-Based Catalytic System}

The $\mathrm{Cu} / \mathrm{ZnO}$ catalysts are well established in SRM reactions due to their high catalytic activity and selectivity [70]. As stated by Butt and Petersen [71], copper particles are prone to sintering and $\mathrm{ZnO}$ can act as a dispersive agent. This characteristic can improve the catalytic performance since the direct contact of copper particles can be limited but also the dispersion of active phase can be enhanced [72,73]. In addition to this structural function, synergy between these two components was observed and reported in various studies [74,75]. According to Spencer [72], the presence of synergy between the two components was verified in terms of catalytic activity, as the activity of this binary system was several orders magnitude greater than that of pure copper or $\mathrm{ZnO}$. However, the origin of this synergy is still under consideration and several models have been proposed for interpreting this phenomenon [76-80]. Grunwaldt et al. [76] presented a model for strong metal-support interactions (SMSI) between copper and zinc oxide. Based on in situ EXAFS and XRD measurements, it was proposed that $\mathrm{ZnO}_{\mathrm{x}}$ species act as a cocoon for copper particles under reducing conditions. The effect of harsher conditions causes surface and bulk alloying and subsequently leads to the formation of brass. These characteristics were verified by d' Alnoncourt et al. [80] after the observation of similar characteristics between copper and zinc species under reducing conditions. Kasatkin et al. [77] found a correlation between the concentration of planar defects of $\mathrm{Cu}$ particles and catalytic activity. Based on HRTEM measurements (Figure 5), it was found that stacking faults and twin boundaries in nanostructured $\mathrm{Cu}$ could create extraordinary geometric and electronic conditions, and thus new active sites might be formed.

Despite their high performance in the SRM reaction, $\mathrm{Cu} / \mathrm{ZnO}$-based catalysts present a major drawback: the absence of long-term stability. Frank et al. [81] pointed out that a decrease of $30-40 \%$ of the initial activity was observed in $\mathrm{Cu} / \mathrm{ZnO}$-based catalysts in combination with different oxide components (Figure 6). A thorough study with respect to the deactivation process on $\mathrm{Cu} / \mathrm{ZnO}$-based catalysts in the SRM reaction was conducted by Twigg and Spencer [82]. The sintering of copper particles was considered as an important aspect of catalyst deactivation. It can be concluded that copper is more susceptible to sintering than other metals, and for this reason the operating temperature of $\mathrm{Cu}$-based catalysts should be carefully controlled (above ca. $330^{\circ} \mathrm{C}$ ), while the pretreatment procedures should be also carefully applied. Furthermore, the operating atmosphere of the catalyst may cause deactivation phenomena. It is worth mentioning that $\mathrm{Cu} / \mathrm{ZnO}$-based catalysts present more stable performance in the methanol synthesis reaction as compared with the SRM reaction, though both of these two reactions occurred in a similar temperature range. It is suggested that the concentration of steam affects the degree of deactivation on $\mathrm{Cu} / \mathrm{ZnO}$ based catalysts, as the sintering in the most oxidic metals is promoted by steam [82]. Other origins of catalyst deactivation come from exposure of $\mathrm{Cu} / \mathrm{ZnO}$-based catalysts in air (pyrophoricity phenomena) and the contamination from sulfur or chlorine [82]. 


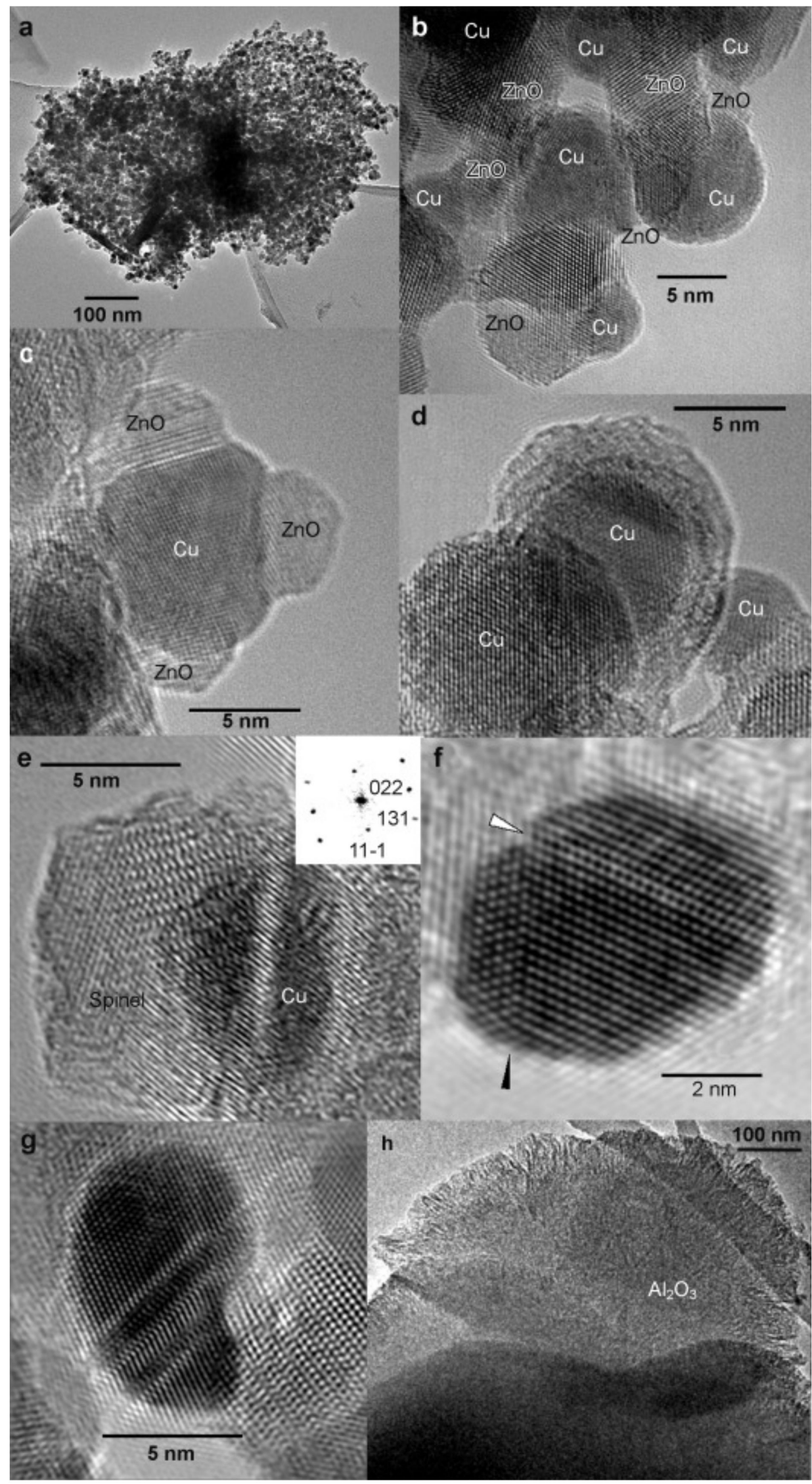

Figure 5. Microstructural characteristics with TEM and HRTEM experiments of the studied $\mathrm{Cu} / \mathrm{ZnO}-$ based catalysts. (Adapted from [77], copyright 2007, John Wiley and Sons.) 


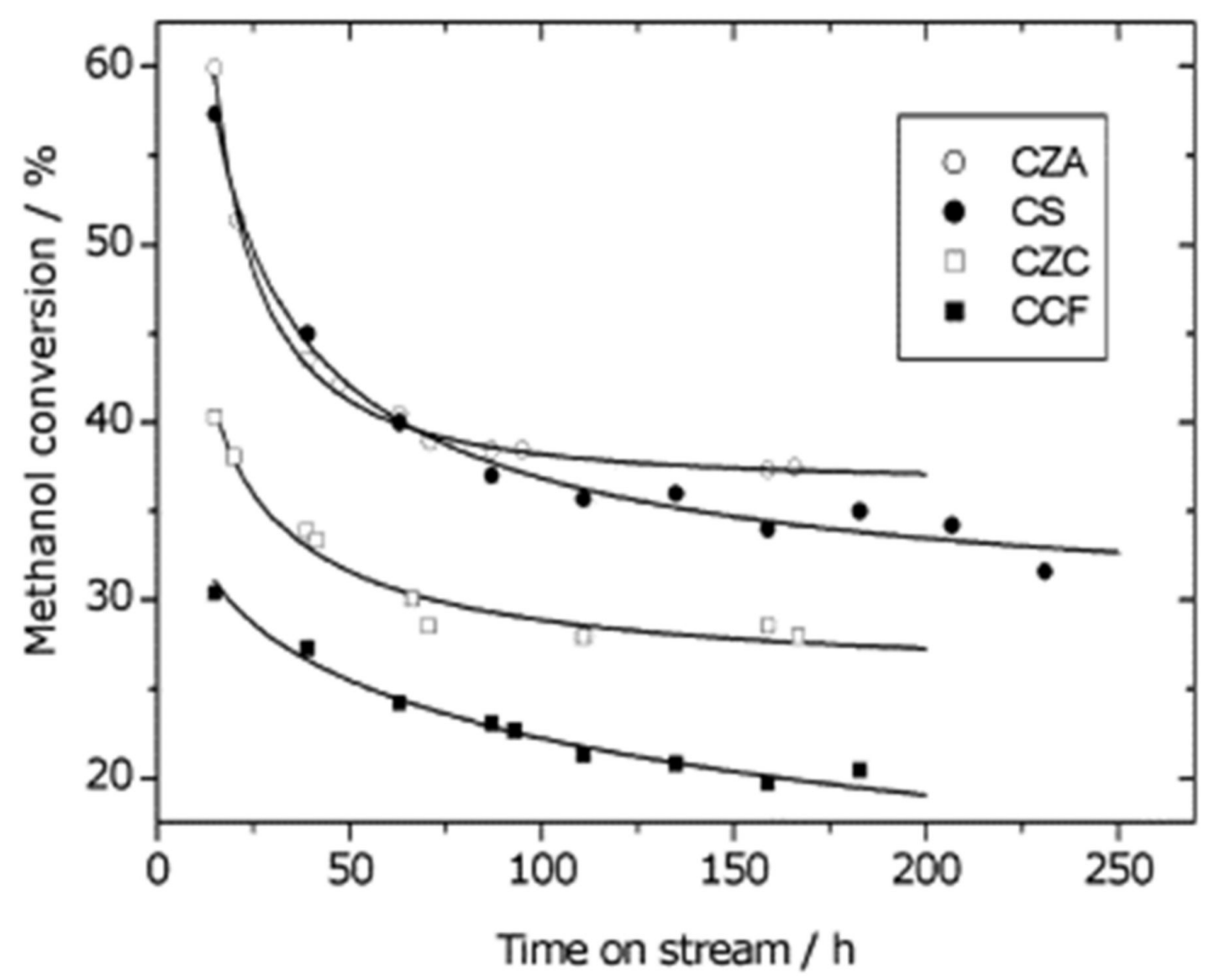

Figure 6. Catalyst deactivation of $\mathrm{Cu}$-based catalysts during the SRM reaction as a function on time of stream. Experimental conditions: $\mathrm{T}=220{ }^{\circ} \mathrm{C}, \mathrm{p}=1 \mathrm{bar}, \mathrm{S} / \mathrm{C}=1$. (CZA: $\mathrm{Cu} / \mathrm{ZnO} / \mathrm{Al}_{2} \mathrm{O}_{3}, \mathrm{CS}: \mathrm{Cu} / \mathrm{SiO}_{2}, \mathrm{CZC}: \mathrm{Cu} / \mathrm{ZnO} / \mathrm{CeO}_{2}, \mathrm{CCF}: \mathrm{Cu} / \mathrm{Cr}_{2} \mathrm{O}_{3} / \mathrm{Fe}_{2} \mathrm{O}_{3}$ ). (Adapted from [81], copyright 2007, Elsevier.)

It can be observed that there are several conditions that can deactivate the $\mathrm{Cu} / \mathrm{ZnO}$ based catalysts during SRM reaction. In order to overcome these deactivation phenomena and enhance the performance of this binary catalytic system, various ways have been developed, including the addition of another oxide material as a stabilizer/promoter for producing ternary and/or quaternary catalytic compositions, and the utilization of different preparation routes. These strategies are reviewed in the next sections.

\subsubsection{Effect of Various Promoters on the Performance of Cu-Based Catalysts}

Besides the widely studied and still debated $\mathrm{ZnO}$, in terms of its role in the SRM reaction, several oxides have been reported to promote the performance of $\mathrm{Cu}$-based catalysts $[43,50,70,83-88]$. However, the beneficial role of $\mathrm{Al}_{2} \mathrm{O}_{3}$ in $\mathrm{Cu}$-based catalysts for the SRM has been scarcely mentioned. According to the literature, $\mathrm{Al}_{2} \mathrm{O}_{3}$ is considered as a structural promoter and has been incorporated in copper-based catalytic systems in order to increase the surface area, the mechanical strength, and the thermal stability of the catalyst $[19,20]$. Huang et al. [83] studied the effect of $\mathrm{Al}_{2} \mathrm{O}_{3}$ on the $\mathrm{SRM}$ for $\mathrm{Cu} / \mathrm{ZnO}$ based catalysts. They found that an appropriate amount of alumina (10 wt.\%) enhanced the stability and the mechanical strength of the catalysts. Moreover, Shishido et al. [84] prepared a ternary $\mathrm{Cu} / \mathrm{ZnO} / \mathrm{Al}_{2} \mathrm{O}_{3}$ catalyst which outperformed the binary $\mathrm{Cu} / \mathrm{ZnO}$ catalyst in terms of activity for the SRM reaction. However, the amount of $\mathrm{Al}_{2} \mathrm{O}_{3}$ should be carefully controlled because at high loadings, the activity of the catalyst could be negatively affected $[83,89]$.

The catalyst performance in SRM can be also promoted by the addition of $\mathrm{ZrO}_{2}$. Various studies have verified that the addition of $\mathrm{ZrO}_{2}$ causes the formation of highly dispersed $\mathrm{Cu}$ and $\mathrm{ZnO}$ particles and this feature can lead to improved activity and stability 
for the SRM reaction [33,85,90-92]. Mateos-Pedrero et al. [33] studied various compositions of $\mathrm{ZrO}_{2}$ and $\mathrm{Al}_{2} \mathrm{O}_{3}$ in order to prepare a stable and efficient support of copper catalysts for the SRM reaction. They illustrated that the dispersion and the reducibility of copper particles increased when the $\mathrm{ZrAl}$ support contained a low amount of $\mathrm{ZrO}_{2}$. This feature enhanced the performance of the prepared catalyst for the SRM reaction. However, the opposite trend was observed at high contents of $\mathrm{ZrO}_{2}$. According to Matsumura and Ishibe [85] the growth of $\mathrm{ZnO}$ particles could be suppressed by the addition of $\mathrm{ZrO}_{2}$ into $\mathrm{Cu} / \mathrm{ZnO}$ based catalysts, resulting in stability enhancement for the SRM reaction at $400{ }^{\circ} \mathrm{C}$. However, a deactivation in the aforementioned ternary catalysts was emerged when the reaction was repeated (Figure 7). This deactivation was considered to take place due to the changes in the interaction of $\mathrm{Cu}$ and $\mathrm{ZnO}$ particles. On the other hand, few studies illustrated that the promotion of $\mathrm{ZrO}_{2}$ was not considered only as a material for protection against the deactivation. The interactions between copper and zirconium dioxide were found to play a significant role in the SRM reaction, as the catalysts containing $\mathrm{ZrO}_{2}$ resulted to be more effective than the $\mathrm{ZrO}_{2}$-absent materials [92,93]. Breen and Ross [92] reported the existence of a synergistic effect between $\mathrm{Cu}$ and $\mathrm{ZrO}_{2}$ that was responsible for better catalytic performance. This phenomenon of synergism was ascribed to the adjustment of active copper species under working conditions. Ceria $\left(\mathrm{CeO}_{2}\right)$ is an attractive oxide that can enrich the performance of copper-based catalysts, due to its extraordinary structural properties $[87,88]$. The addition of ceria into $\mathrm{Cu}$-based catalysts leads to improved physicochemical characteristics over the $\mathrm{Cu}$-based catalysts, while the strong metal-support interaction between copper and ceria particles can enhance the activity and the stability of catalysts [87,88,94-97]. Minaei et al. [95] prepared a series of quaternary $\mathrm{CuO} / \mathrm{ZnO} / \mathrm{CeO}_{2} / \mathrm{Al}_{2} \mathrm{O}_{3}$ catalysts via the urea-nitrates combustion method for the production of $\mathrm{H}_{2}$ through the SRM reaction. The experimental results indicated an optimum portion of $\mathrm{CeO}_{2}(10 \mathrm{wt}$.\%), which could promote the physicochemical properties of the quaternary system and thus the catalytic activity and hydrogen selectivity for the SRM reaction. Patel et al. [97] studied the effect of $\mathrm{Ce}$ and $\mathrm{Zn}$ promoters on the Cu-based catalysts. Interestingly, the $\mathrm{Ce}$ promoted $\mathrm{CuO} / \mathrm{ZnO} / \mathrm{CeO}_{2} / \mathrm{Al}_{2} \mathrm{O}_{3}$ catalysts and illustrated higher activity and selectivity at low temperatures for the SRM reaction. Moreover, the quaternary copper-based system showed enhanced stability over prolonged operating time with respect to the catalysts which were promoted only with $\mathrm{ZnO}$. It is worth mentioning that the morphology of ceria plays an important role for the SRM reaction. Yang et al. [87] prepared various $\mathrm{CeO}_{2}$ morphologies (nanorods (R), nanoparticles (P), and sponginess (S)) that were used as supports for copper catalysts (Figure 8). The $\mathrm{CuO} / \mathrm{CeO}_{2}$ catalyst with nanorod ceria presented the highest activity among the other catalysts due to the highest amount of active copper species and increased concentration of oxygen vacancies.

There are several reports which highlighted the promoting role of gallium oxide on Cu-based catalysts for methanol synthesis and SRM processes [43,50,98-103]. The research group of Chang $[43,98,100]$ developed a new series of Ga promoted Cu/ZnO-based catalysts via a facile coprecipitation method. This ternary system illustrated tremendous performance for SRM and achieved high catalytic activity at temperature lower than $200^{\circ} \mathrm{C}$. Through the utilization of advanced physicochemical techniques, they proposed that non-stoichiometric cubic spinels were formed during the incorporation of $\mathrm{Ga}$ into the $\mathrm{Cu}-\mathrm{Zn}$ oxide. This spinel phases contained interstitial $\mathrm{Cu}^{+}$ions which during in situ conditions could produce a vast number of extremely small and highly dispersed copper clusters (5 $\AA$ ) on a defective $\mathrm{ZnGa}_{2} \mathrm{O}_{4}$ structure. Moreover, Ribeirinha et al. [50] prepared a novel $\mathrm{CuO} / \mathrm{ZnO} / \mathrm{Ga}_{2} \mathrm{O}_{3}$ catalyst which showed higher activity (2.2 times) for SRM, than commercial copper-based catalysts at $200{ }^{\circ} \mathrm{C}$. In addition to the aforementioned promoters/stabilizers several others, such as Mn [104,105], Cr [106,107], and Fe [108,109], were investigated for the improvement of $\mathrm{Cu}$-based catalysts and are reviewed in the Table 2. 


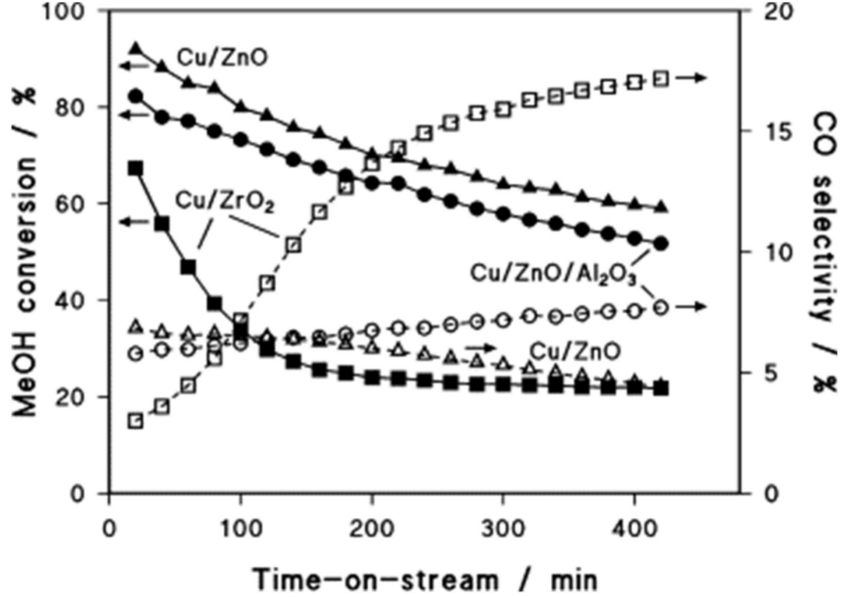

(a)

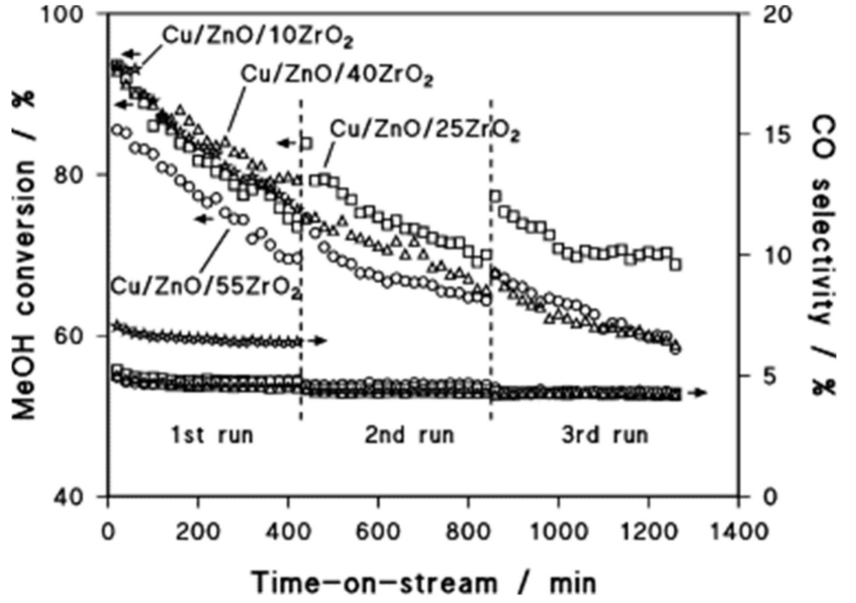

(b)

Figure 7. (a) Catalytic activity of $\mathrm{Cu}$-based catalysts in the SRM reaction at $400{ }^{\circ} \mathrm{C}$. Experimental conditions and symbolism: $\left(\mathrm{F} / \mathrm{W}, 1.6 \mathrm{dm}^{3} \mathrm{~min}^{-1} \mathrm{~g}^{-1}\right)$, (Circle symbols, $\mathrm{Cu} / \mathrm{ZnO} / \mathrm{Al}_{2} \mathrm{O}_{3}$; triangle, $\mathrm{Cu} / \mathrm{ZnO}$; square, $\mathrm{Cu} / \mathrm{ZrO}_{2}$ ); (b) Catalytic activity of $\mathrm{Cu} / \mathrm{ZnO} / \mathrm{ZrO}_{2}$ in the SRM reaction at $400{ }^{\circ} \mathrm{C}$. Experimental conditions and symbolism: $\left(\mathrm{F} / \mathrm{W}, 1.6 \mathrm{dm}^{3} \mathrm{~min}^{-1} \mathrm{~g}^{-1}\right),(\mathrm{Star}$ symbols $\mathrm{Cu} / \mathrm{ZnO} / 10 \mathrm{ZrO}_{2}$; square, $\mathrm{Cu} / \mathrm{ZnO} / 25 \mathrm{ZrO}_{2}$; triangle, $\mathrm{Cu} / \mathrm{ZnO} / 40 \mathrm{ZrO}_{2}$; circle, $\mathrm{Cu} / \mathrm{ZnO} / 55 \mathrm{ZrO}{ }_{2}$ ). (Adapted from [85], copyright 2009, Elsevier.)

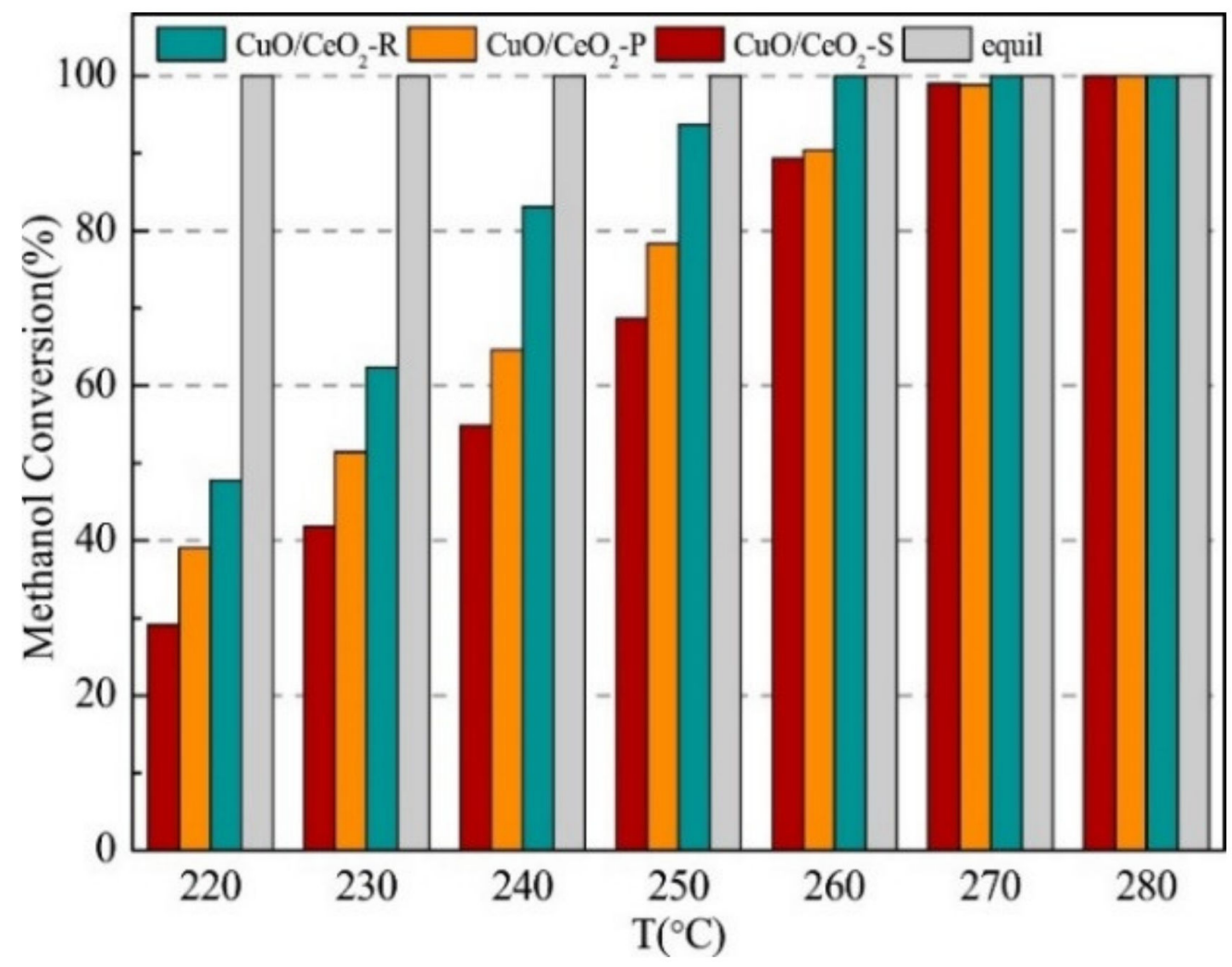

Figure 8. Catalytic activity for the SRM reaction as a function of temperature. (Experimental conditions: $\mathrm{S} / \mathrm{C}=1.2, \mathrm{GHSV}=800 \mathrm{~h}^{-1}$, no carrier gas.) (Adapted from [87], copyright 2019, Elsevier.) 
Table 2. Influence of various promoters on the performance of $\mathrm{Cu}$-based catalysts for SRM reaction.

\begin{tabular}{|c|c|c|c|c|c|c|c|}
\hline Catalyst & $\mathrm{S} / \mathrm{C}$ & $\mathrm{T}\left({ }^{\circ} \mathrm{C}\right)$ & $\mathrm{X}_{\mathrm{MeOH}}{ }^{1}(\%)$ & $\mathrm{S}_{\mathrm{CO}}{ }^{2}(\%)$ & $\begin{array}{c}\text { Hydrogen } \\
\text { Production } \\
\text { Rate } \\
\left(\mu \mathrm{mol}_{\mathrm{H} 2} / \mathrm{g}_{\text {cat }} \mathrm{s}\right)\end{array}$ & $\begin{array}{c}\mathrm{W} / \mathrm{F} \\
(\mathrm{g} \mathrm{s} / \mathrm{mL})\end{array}$ & Reference \\
\hline $\mathrm{Cu} / \mathrm{ZrO}_{2} / \mathrm{Al}_{2} \mathrm{O}_{3}$ & 1.5 & 220 & 90 & 0.10 & - & - & {$[33]$} \\
\hline $\begin{array}{c}\mathrm{Cu} / \mathrm{ZnO} / \mathrm{Al}_{2} \mathrm{O}_{3} \\
\mathrm{Cu} / \mathrm{ZnO} / \mathrm{ZrO}_{2} / \mathrm{Al}_{2} \mathrm{O}_{3}\end{array}$ & 1.1 & 270 & $\begin{array}{l}89.2 \\
92.4\end{array}$ & $\begin{array}{l}0.92 \\
0.97\end{array}$ & - & - & [83] \\
\hline $\begin{array}{c}\mathrm{Cu} / \mathrm{ZnO} \\
\mathrm{Cu} / \mathrm{ZnO} / \mathrm{Al}_{2} \mathrm{O}_{3}\end{array}$ & 1.2 & 250 & $\begin{array}{c}90.0 \\
100.0\end{array}$ & - & - & 0.46 & [84] \\
\hline $\mathrm{Cu} / \mathrm{CeO}_{2}$ & 1.2 & 260 & 100.0 & 2.40 & $15.3^{3}$ & & {$[87]$} \\
\hline $\mathrm{Cu} / \mathrm{ZnO} / \mathrm{CeO}_{2} / \mathrm{Al}_{2} \mathrm{O}_{3}$ & 1.5 & 220 & 80.0 & 0.00 & - & 0.36 & [95] \\
\hline $\begin{array}{c}\mathrm{Cu} / \mathrm{Al}_{2} \mathrm{O}_{3} \\
\mathrm{Cu} / \mathrm{ZnO} / \mathrm{Al}_{2} \mathrm{O}_{3} \\
\mathrm{Cu} / \mathrm{ZnO} / \mathrm{CeO}_{2} / \mathrm{Al}_{2} \mathrm{O}_{3}\end{array}$ & 1.4 & 260 & $\begin{array}{l}31.0 \\
76.0 \\
90.0 \\
\end{array}$ & & $\begin{array}{l}81.0^{3} \\
203.0 \\
244.0\end{array}$ & - & [97] \\
\hline $\mathrm{Cu} / \mathrm{ZnO} / \mathrm{Ga}_{2} \mathrm{O}_{3}$ & 2.0 & 150 & 22.5 & 0.00 & $109.3^{4}$ & & [98] \\
\hline $\begin{array}{c}\mathrm{CuMnO} \text { spinel } \\
\mathrm{CuCeO}_{\mathrm{x}}\end{array}$ & 1.5 & 240 & $\begin{array}{l}99.0 \\
37.0 \\
\end{array}$ & $\begin{array}{l}3.1 \\
0.8 \\
\end{array}$ & - & 0.26 & [104] \\
\hline $\mathrm{Cu}_{X} \mathrm{Fe}_{1-\mathrm{x}} \mathrm{Al}_{2} \mathrm{O}_{4}$ & 1.1 & 275 & $>90.0$ & $<5.0$ & - & 0.12 & [109] \\
\hline $\begin{array}{c}\mathrm{Cu} / \mathrm{ZnO} \\
\mathrm{Cu} / \mathrm{ZnO} / \mathrm{Al}_{2} \mathrm{O}_{3} \\
\mathrm{Cu} / \mathrm{ZnO} / \mathrm{ZrO}_{2} / \mathrm{Al}_{2} \mathrm{O}_{3} \\
\end{array}$ & 1.3 & 260 & $\begin{array}{l}75 \\
79 \\
92 \\
\end{array}$ & $\begin{array}{l}- \\
- \\
-\end{array}$ & $\begin{array}{l}- \\
- \\
-\end{array}$ & 0.06 & [110] \\
\hline $\mathrm{Cu} / \mathrm{ZnO} / \mathrm{Al}_{2} \mathrm{O}_{3}$ & 2.0 & 250 & 84.3 & 1.50 & - & - & [111] \\
\hline $\begin{array}{c}\mathrm{Cu} / \mathrm{ZnO} \\
\mathrm{Cu} / \mathrm{ZnO} / \mathrm{Al}_{2} \mathrm{O}_{3} \\
\mathrm{Cu} / \mathrm{ZnO} / \mathrm{ZrO}_{2} \\
\mathrm{Cu} / \mathrm{ZnO} / \mathrm{CeO}_{2}\end{array}$ & 1.2 & 250 & $\begin{array}{l}68.0 \\
75.0 \\
97.0 \\
80.0\end{array}$ & $\begin{array}{l}0.30 \\
1.80 \\
0.80 \\
0.25 \\
\end{array}$ & $\begin{array}{c}309.0^{3} \\
340.0 \\
553.0 \\
392.0 \\
\end{array}$ & - & [112] \\
\hline $\begin{array}{c}\mathrm{Cu} / \mathrm{CeO}_{2} \\
\mathrm{Cu} / \mathrm{CeO}_{2} / \mathrm{ZrO}_{2}\end{array}$ & 1.5 & 250 & $\begin{array}{c}>80.0 \\
- \\
\end{array}$ & - & $\begin{array}{l}75.0 \\
97.0\end{array}$ & 0.22 & [113] \\
\hline $\mathrm{Cu} / \mathrm{ZnO} / \mathrm{Ga}_{2} \mathrm{O}_{3}$ & 1.3 & 320 & 96.0 & - & 198.0 & 1.00 & {$[114]$} \\
\hline $\begin{array}{l}\mathrm{Cu} / \mathrm{ZnO} \\
\mathrm{Cu} / \mathrm{Cr}_{2} \mathrm{O}_{3}\end{array}$ & 1.0 & 240 & - & $\begin{array}{c}7.00 \\
14.00 \\
\end{array}$ & $\begin{array}{l}24.0 \\
17.0\end{array}$ & 0.05 & [115] \\
\hline $\mathrm{Cu} / \mathrm{Fe} / \mathrm{SiO}_{2}$ & & 180 & 99.0 & - & - & - & [116] \\
\hline
\end{tabular}

${ }^{1}$ Methanol conversion, ${ }^{2} \mathrm{CO}$ selectivity, ${ }^{3}$ the unit is $\left(\mathrm{mmol}_{\mathrm{H} 2} / \mathrm{kg}_{\text {cat }} / \mathrm{s}\right),{ }^{4}$ the unit is $\left(\mathrm{cm}^{3} \mathrm{H} 2 / \mathrm{kg}_{\text {cat }} / \mathrm{s}\right)$.

\subsubsection{Effect of Preparation Methods on the Performance of Cu-Based Catalysts}

The catalytic performance of $\mathrm{Cu}$-based catalysts can be improved by the utilization of different preparation routes. Various catalytic formulations can be prepared by different preparation routes and illustrate different performances for the SRM process $[34,89,117]$. The influence of different preparation methods on the performance of $\mathrm{Cu}$-based catalysts is presented in Table 3. Except for traditional preparation methods such as coprecipitation (CP) $[98,118]$, wet impregnation (WI) [119,120], hydrothermal synthesis (HT) [121,122], and solution-combustion synthesis (SCS) [94,105], the innovative optimization of the traditional ones and the finding of new preparation methods is proposed in order to develop $\mathrm{Cu}$ based catalysts with attractive physicochemical characteristics and performance for the SRM reaction. 
Table 3. Influence of various preparation methods on the performance of $\mathrm{Cu}$-based catalysts.

\begin{tabular}{|c|c|c|c|c|c|c|c|c|}
\hline Catalyst & $\begin{array}{l}\text { Preparation } \\
\text { Method }\end{array}$ & $\mathrm{S} / \mathrm{C}$ & $\begin{array}{c}\mathrm{T} \\
\left({ }^{\circ} \mathrm{C}\right)\end{array}$ & $\underset{(\%)}{\mathrm{X}_{\mathrm{MeOH}}{ }^{1}}$ & $\mathrm{~S}_{\mathrm{CO}}{ }^{2}(\%)$ & $\begin{array}{c}\text { Hydrogen } \\
\text { Production } \\
\text { Rate } \\
\left(\mu \mathrm{mol}_{\mathrm{H} 2} / \mathrm{g}_{\text {cat }} \mathrm{s}\right)\end{array}$ & $\begin{array}{c}\text { W/F } \\
\text { (g s/mL) }\end{array}$ & Reference \\
\hline \multirow{4}{*}{$\mathrm{Cu} / \mathrm{ZnO} / \mathrm{Al}_{2} \mathrm{O}_{3}$} & $\mathrm{HT}$ & \multirow{4}{*}{1.50} & \multirow{4}{*}{240} & $<20.0$ & - & - & \multirow{4}{*}{0.36} & \multirow{4}{*}{ [31] } \\
\hline & $\mathrm{CP}$ & & & 93.0 & 0.28 & - & & \\
\hline & PHT & & & $<35.0$ & - & - & & \\
\hline & PCP & & & 95.0 & 0.23 & - & & \\
\hline \multirow{2}{*}{$\mathrm{Cu} / \mathrm{ZnO} / \mathrm{ZrO}_{2} / \mathrm{Al}_{2} \mathrm{O}_{3}$} & WI & \multirow{2}{*}{1.40} & \multirow{2}{*}{260} & 60.0 & - & 159.0 & \multirow{2}{*}{$11.00^{3}$} & \multirow{2}{*}[34]{} \\
\hline & $\mathrm{CP}$ & & & 97.0 & - & 261.0 & & \\
\hline \multirow{3}{*}{$\mathrm{Cu} / \mathrm{ZrO}_{2}$} & WI & \multirow{3}{*}{1.30} & \multirow{3}{*}{260} & 10.0 & - & 3.0 & \multirow{3}{*}{-} & \multirow{3}{*}{ [117] } \\
\hline & $\mathrm{CP}$ & & & 62.0 & - & 56.0 & & \\
\hline & OGCP & & & 100.0 & - & 90.0 & & \\
\hline \multirow{3}{*}{$\mathrm{Cu} / \mathrm{ZnO} / \mathrm{Al}_{2} \mathrm{O}_{3}$} & WI & \multirow{3}{*}{1.43} & \multirow{3}{*}{230} & $<60.0$ & - & & \multirow{3}{*}{-} & \multirow{3}{*}{ [121] } \\
\hline & $\mathrm{HT}$ & & & $<80.0$ & - & - & & \\
\hline & $\mathrm{CP}$ & & & $<99.0$ & - & & & \\
\hline \multirow{2}{*}{$\mathrm{Cu} / \mathrm{ZnO} / \mathrm{Al}_{2} \mathrm{O}_{3}$} & MC & \multirow{2}{*}{1.5} & \multirow{2}{*}{240} & 100.0 & $<3.0$ & - & \multirow{2}{*}{0.36} & \multirow{2}{*}{ [123] } \\
\hline & CC & & & 90.0 & 3.0 & 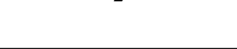 & & \\
\hline \multirow{2}{*}{$\mathrm{Cu} / \mathrm{ZnO} / \mathrm{ZrO}_{2} / \mathrm{Al}_{2} \mathrm{O}_{3}$} & $\mathrm{CP}$ & \multirow{2}{*}{1.5} & \multirow{2}{*}{200} & 84.0 & - & - & \multirow{2}{*}{0.36} & \multirow{2}{*}{ [124] } \\
\hline & SCP & & & 100.0 & - & - & & \\
\hline
\end{tabular}

\footnotetext{
${ }^{1}$ Methanol conversion, ${ }^{2} \mathrm{CO}$ selectivity, ${ }^{3}$ the unit is $\left(\mathrm{kg}_{\mathrm{cat}} \mathrm{s} / \mathrm{mol}\right)$. HT: Hydrothermal synthesis, CP: Coprecipitation, HTP: Plasma assisted hydrothermal synthesis, PCP: Plasma assisted coprecipitation, WI: Wet impregnation, OGCP: Oxalate gel coprecipitation, MC: Microwave combustion method, CC: Conventional combustion method, SCP: Sonochemical assisted coprecipitation.
}

Yao et al. [117] employed several preparation routes (impregnation, oxalate-gel coprecipitation, and conventional coprecipitation) in order to prepare $\mathrm{Cu} / \mathrm{ZrO}_{2}$ catalysts. The binary catalytic system prepared via the oxalate-gel optimization presented the higher copper surface area and copper dispersion, and thus it exhibited the highest methanol conversion. Moreover, the obtained catalyst indicated significant stability for the SRM reaction as compared with the other catalysts. Sanches et al. [125] studied the effect of different preparation methods, namely, coprecipitation, sequential coprecipitation, and homogeneous coprecipitation, over the $\mathrm{Cu} / \mathrm{ZnO}$ binary catalysts for the SRM reaction. The physicochemical characteristics and subsequently the catalytic activity could be influenced by the studied preparation methods. The $\mathrm{Cu} / \mathrm{ZnO}$ catalysts prepared via homogeneous precipitation showed the highest methanol conversion among the studied catalysts but with significant amount of $\mathrm{CO}$ in the outlet stream.

Bagherzadeh and Haghighi [31] prepared a series of $\mathrm{CuO} / \mathrm{ZnO} / \mathrm{Al}_{2} \mathrm{O}_{3}$ catalysts via hydrothermal and coprecipitation routes. Besides the utilization of the aforementioned preparation methods, the innovative treatment of non-thermal plasma was used as an additional stage in the experimental procedure. From field emission scanning electron microscopy (FESEM) studies (Figure 9), it was shown that the non-thermal plasma assisted coprecipitation method resulted in a ternary catalyst with the most uniform morphology and particle's size distribution among the other prepared catalysts. The catalytic studies demonstrated the enhanced functionality of the catalyst prepared with the plasma assisted coprecipitation route in terms of activity, CO selectivity, and stability. The homogeneous precipitation method and the urea combustion method were also investigated by Talkhoncheh et al. [45] for the synthesis of $\mathrm{Cu} / \mathrm{ZnO}$-based catalysts for hydrogen production via the SRM process. The catalytic results illustrated that the former synthesis route provided catalysts with high methanol conversion and low CO selectivity. 

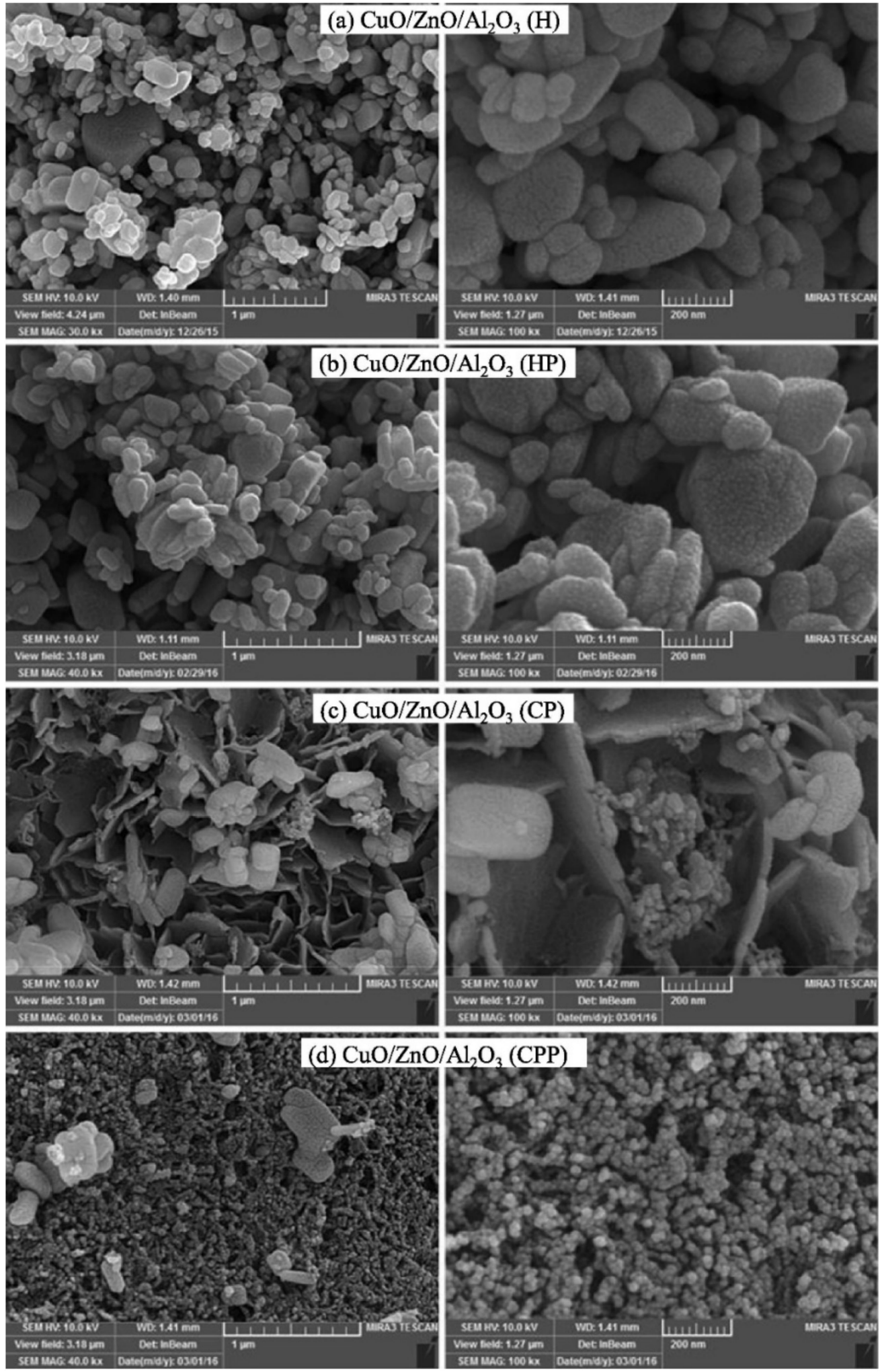

Figure 9. FESEM images of synthesized catalysts: (a) $\mathrm{CuO} / \mathrm{ZnO} / \mathrm{Al}_{2} \mathrm{O}_{3}$ (Hydrothermal synthesis, $\mathrm{H}$ ), (b) $\mathrm{CuO} / \mathrm{ZnO} / \mathrm{Al}_{2} \mathrm{O}_{3}$ (Plasma assisted Hydrothermal synthesis, $\mathrm{HP}$ ), (c) $\mathrm{CuO} / \mathrm{ZnO} / \mathrm{Al}_{2} \mathrm{O}_{3}$ (Coprecipitation method, $\mathrm{CP}$ ), and (d) $\mathrm{CuO} / \mathrm{ZnO} / \mathrm{Al}_{2} \mathrm{O}_{3}$ (Plasma-assisted Coprecipitation method, CPP). (Adapted from [31], copyright 2017, Elsevier.) 


\subsubsection{Reaction Mechanism}

The reaction mechanism which governs the steam reforming of methanol over $\mathrm{Cu}$ based catalysts, has been extensively over the years $[2,18,26]$. The production of hydrogen through SRM is mainly considered to be accomplished via the MD and WGS reactions (see Equations (1) and (4), respectively) [126,127]. According to this mechanism, CO is suggested to be the primary product and thus, the concentration of $\mathrm{CO}$ in the product stream should be higher than the equilibrium. Nevertheless, experimental results have shown that $\mathrm{Cu}$-based catalysts are able to produce a gas stream with low concentration in CO $[127,128]$, and for this reason, this model has been abandoned for interpreting the mechanism of the SRM reaction over Cu-based catalysts.

A different mechanism which involves a methyl formate intermediate was suggested by Takahashi et al. [129]. According to this work and the suggested model, methyl formate and hydrogen were produced via the dehydrogenation of methanol, followed by the hydrolyzation of methyl formate, thus leading to the production of formic acid and methanol. Then, carbon dioxide and hydrogen were formed by the decomposition of formic acid. It is interesting to note, that $\mathrm{CO}$ was not considered as a primary product and its main source of production was via rWGS reaction. This model was supported by Jiang et al. [130], where a Langmuir-Hinshelwood rate expression was proposed, based on a single kind of active sites. Peppley et al. [131] developed a more optimized and comprehensive model for the methyl formate intermediate mechanism, where two active sites were involved: one for SRM and WGS reactions and one other for the MD reaction. This model was supported by various studies $[26,81,92,132,133]$. For instance, Breen and Ross [92] observed the formation of methyl formate on the surface of $\mathrm{Cu}$-based catalysts which afterwards, was decomposed to $\mathrm{CO}_{2}$ and $\mathrm{H}_{2}$.

$$
\begin{array}{cc}
2 \mathrm{CH}_{3} \mathrm{OH} \rightarrow \mathrm{HCOOCH}_{3}+2 \mathrm{H}_{2} & \Delta \mathrm{H}^{0}=+64.4 \mathrm{~kJ} / \mathrm{mol} \\
\mathrm{HCOOCH}_{3}+\mathrm{H}_{2} \mathrm{O} \rightarrow \mathrm{CH}_{3} \mathrm{OH}+\mathrm{HCOOH} & \Delta \mathrm{H}^{0}=-31.1 \mathrm{~kJ} / \mathrm{mol} \\
\mathrm{HCOOH} \rightarrow \mathrm{CO}_{2}+\mathrm{H}_{2} & \Delta \mathrm{H}^{0}=+31.2 \mathrm{~kJ} / \mathrm{mol}
\end{array}
$$

Takezawa and Iwasa [134] developed an alternative mechanism, where the intermediate products were to be the formaldehyde and the formic acid. Similarly in this case, CO was produced via the rWGS reaction. This model was supported by Shishido et al. [84] who confirmed the dehydrogenation of methanol to formaldehyde and, then, the hydrolyzation of the latter to formic acid. Then, formic acid was decomposed to the main products of SRM reaction.

$$
\begin{array}{cc}
\mathrm{CH}_{3} \mathrm{OH} \rightarrow \mathrm{HCHO}+\mathrm{H}_{2} & \Delta \mathrm{H}^{0}=+92.2 \mathrm{~kJ} / \mathrm{mol} \\
\mathrm{HCHO}+\mathrm{H}_{2} \mathrm{O} \rightarrow \mathrm{HCOOH}+\mathrm{H}_{2} & \Delta \mathrm{H}^{0}=-74.3 \mathrm{~kJ} / \mathrm{mol} \\
\mathrm{HCOOH} \rightarrow \mathrm{CO}_{2}+\mathrm{H}_{2} & \Delta \mathrm{H}^{0}=+31.2 \mathrm{~kJ} / \mathrm{mol}
\end{array}
$$

Frank et al. [81] gathered all the proposed models for interpreting the hydrogen production through SRM reaction and illustrated a catalytic cycle (Figure 10) of steam reforming of methanol. The dissociative adsorption of methanol on the surface of the catalyst was considered as the rate determining step of the catalytic cycle. Furthermore, it was proposed that there were two different kinds of active sites: the active site $\mathrm{A}\left(\mathrm{S}_{\mathrm{A}}\right)$, which was responsible for the hydrogen adsorption, and the active site $B\left(S_{B}\right)$, which was responsible for the adsorption of all other intermediates. 


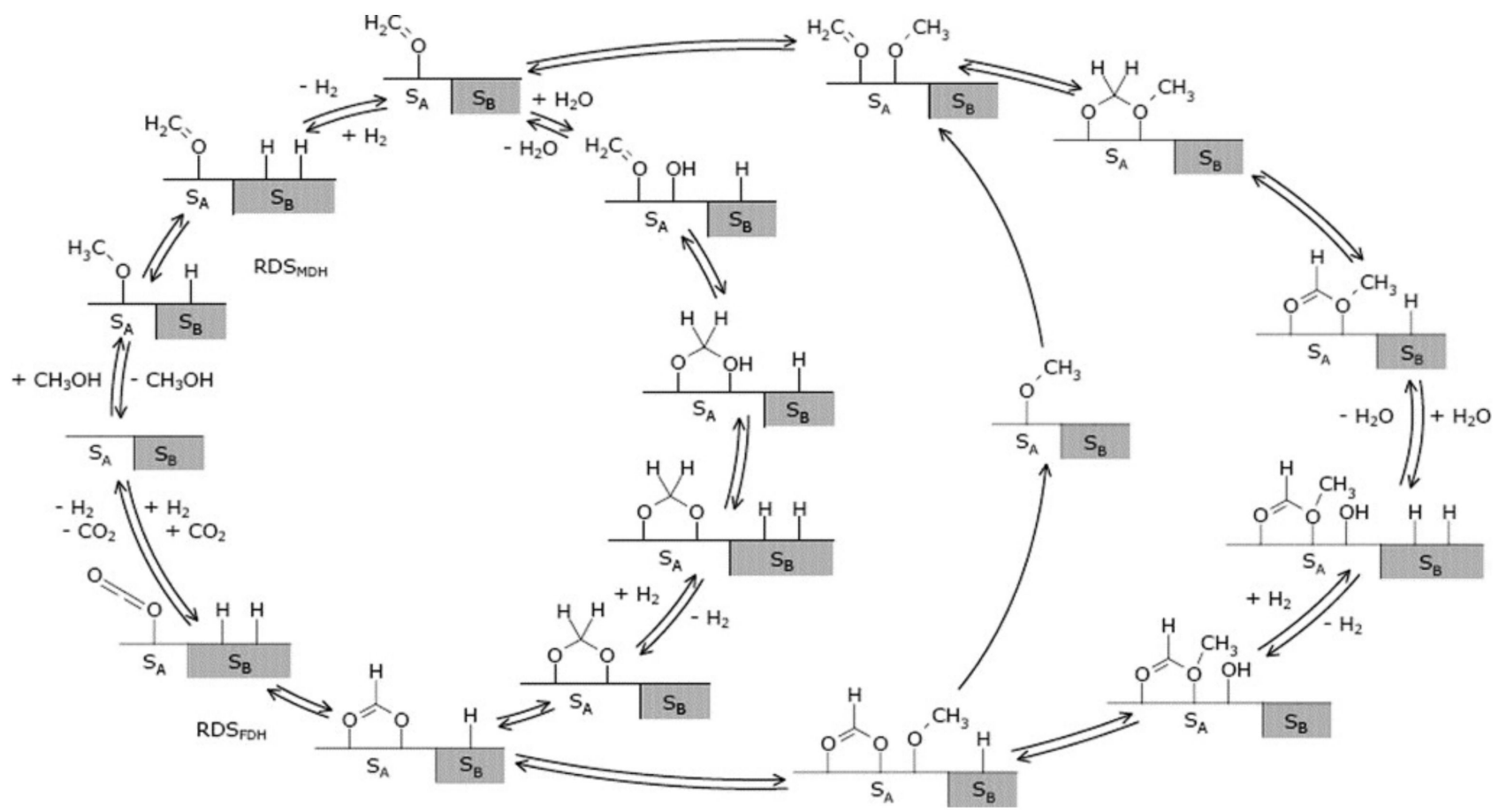

Figure 10. The proposed catalytic cycle of SRM reaction, including different kind of active surface sites: $S_{A}$ and $S_{B}$. (Adapted from [81], copyright 2007, Elsevier.)

Two more mechanisms were also included in this catalytic cycle. One was proposed by Zhang et al. [135] where the methanol dehydrogenation led to the formation of formaldehyde, and then the latter was attacked by a methoxy group for producing methyl formate. The methyl formate was decomposed into methoxy and formate groups with the aid of hydroxyl groups. The other mechanism included the reaction of formaldehyde with the hydroxyl surface groups in order to form dioxomethylene. Following this step, the continuous dehydrogenation of dioxomethylene took place, which resulted in the formation of carbon dioxide and hydrogen.

Papavasiliou et al. [133] conducted a mechanistic study over $\mathrm{CuMnO}_{x}, \mathrm{CuCeO}_{x}$, and $\mathrm{CuZnAlO}_{\mathrm{x}}$ catalysts in order to clarify the reaction mechanism of SRM reaction. They carried out steady-state isotopic transient kinetic analysis (SSITKA) and observed that the $\mathrm{CuMnO}_{\mathrm{x}}$ catalyst followed the route with the methyl formate intermediate, whereas for the other two catalysts, the reaction was taking place via the dioxomethylene intermediate.

Taking all the above findings into consideration, it can be concluded that there is a lot of controversy for the kinetics of SRM reaction, but the most credible model for interpreting the mechanistic route of this reaction seems to be the mechanism with the methyl formate intermediate product.

\subsection{Group 8-10 Catalysts}

As mentioned above, the high activity and selectivity of $\mathrm{Cu}$-based catalysts make them an attractive option for the SRM reaction. However, the deactivation phenomena that take place for the former category and especially the sintering of the active phase at temperatures higher than $260-280^{\circ} \mathrm{C}$, drive the research community to find alternative efficient catalytic systems. Group 8-10 catalysts are highly active for the SRM reaction and though a large amount of $\mathrm{CO}$ is produced during the reaction, this category of catalysts is still in research due to the high stability that illustrate $[2,18,70]$. Moreover, a significant drawback for commercial use of these catalyst is their high cost. In Table 4, various catalysts from group 8-10 are summarized. 
Table 4. Summary of various group 8-10 catalysts used in steam reforming of methanol.

\begin{tabular}{|c|c|c|c|c|c|c|c|}
\hline Catalyst & $\mathrm{S} / \mathrm{C}$ & $\mathrm{T}\left({ }^{\circ} \mathrm{C}\right)$ & $\mathrm{X}_{\mathrm{MeOH}}{ }^{1}(\%)$ & $\mathrm{S}_{\mathrm{CO}}{ }^{2}(\%)$ & $\begin{array}{c}\text { Hydrogen } \\
\text { Production Rate } \\
\left(\mu \mathrm{mol}_{\mathrm{H} 2} / \mathrm{g}_{\text {cat }} \mathrm{s}\right)\end{array}$ & $\begin{array}{c}\text { W/F } \\
(\mathrm{g} \mathrm{s} / \mathrm{mL})\end{array}$ & Reference \\
\hline $\begin{array}{c}\mathrm{Pt} / \mathrm{In}_{2} \mathrm{O}_{3} / \mathrm{Al}_{2} \mathrm{O}_{3} \\
\mathrm{Pt} / \mathrm{In}_{2} \mathrm{O}_{3} / \mathrm{CeO}_{2}\end{array}$ & - & 325 & $\begin{array}{l}98.7 \\
84.8\end{array}$ & $\begin{array}{l}2.6 \\
2.6\end{array}$ & $\begin{array}{l}85.3 \\
92.5\end{array}$ & 0.28 & [38] \\
\hline $\begin{array}{c}\mathrm{Pd} / \mathrm{ZnO} \\
\mathrm{Pd} / \mathrm{ZnO} / \mathrm{Al}_{2} \mathrm{O}_{3} \\
\mathrm{Cu} / \mathrm{ZnO} / \mathrm{Al}_{2} \mathrm{O}_{3} \\
\text { (commercial) }\end{array}$ & 1.78 & 220 & $\begin{array}{l}14.3 \\
46.5 \\
46.3\end{array}$ & $\begin{array}{l}- \\
- \\
-\end{array}$ & $\begin{array}{c}1616.0^{3} \\
4100.0 \\
4175.0\end{array}$ & 0.25 & [136] \\
\hline $\begin{array}{c}\mathrm{Pd} / \mathrm{ZnO} \\
\mathrm{Pd} / \mathrm{ZrO}_{2} \\
\mathrm{Pd} / \mathrm{In}_{2} \mathrm{O}_{3} \\
\mathrm{Pt} / \mathrm{ZnO} \\
\mathrm{Pt} / \mathrm{In}_{2} \mathrm{O}_{3}\end{array}$ & - & 220 & $\begin{array}{c}54.2 \\
64.3 \\
28.3 \\
27.6 \\
1.7 \\
\end{array}$ & $\begin{array}{c}0.8 \\
81.6 \\
4.5 \\
4.6 \\
30.6\end{array}$ & $\begin{array}{l}- \\
- \\
- \\
- \\
-\end{array}$ & - & [137] \\
\hline $\begin{array}{c}\alpha-\mathrm{MoC} \\
0.5 \mathrm{Zn}-\mathrm{Pt} / \mathrm{MoC}\end{array}$ & 3.00 & 160 & $\begin{array}{c}1.4 \\
65.9 \\
\end{array}$ & $\begin{array}{l}0.03 \\
0.00\end{array}$ & $\begin{array}{c}0.6 \\
29.7\end{array}$ & - & [138] \\
\hline $\begin{array}{c}\mathrm{Pd} / \mathrm{ZnO} \\
\mathrm{Pd} / \mathrm{ZnO} / \mathrm{CeO}_{2}\end{array}$ & 1.00 & 300 & $\begin{array}{l}65.0 \\
95.0 \\
\end{array}$ & - & - & 0.05 & [139] \\
\hline $\mathrm{Ni}-\mathrm{Zn}-\mathrm{Al}$ & 1.40 & 500 & 100 & $\sim 30.00$ & - & - & [140] \\
\hline $\mathrm{Ni} / \mathrm{CeO}_{2}$ & 3.00 & 400 & 100 & - & - & - & [141] \\
\hline $\mathrm{Co} / \mathrm{ZnO}$ & - & 220 & 20.3 & 91.1 & - & - & [142] \\
\hline
\end{tabular}

\subsubsection{Pd-Based Catalysts}

Iwasa et al. [143-145] was the first group who studied the utilization of Pd-based catalysts for the SRM reaction. In their first publication [142], they investigated the influence of the support $\left(\mathrm{ZnO}, \mathrm{Al}_{2} \mathrm{O}_{3}, \mathrm{SiO}_{2}, \mathrm{La}_{2} \mathrm{O}_{3}, \mathrm{Nb}_{2} \mathrm{O}_{5}, \mathrm{Nb}_{2} \mathrm{O}_{3}\right.$, and $\left.\mathrm{ZrO}_{2}\right)$ on the performance of Pd-based catalysts for the SRM reaction. It is noteworthy to mention that unsupported $\mathrm{Pd}$ was more prone to the MD reaction, and resulted in high amounts of undesired $\mathrm{CO}$ in the gas product stream [134]. Interestingly, the selectivity for SRM was anomalously higher for the $\mathrm{Pd} / \mathrm{ZnO}$ catalysts with respect to other supported catalysts. Further investigation by Iwasa et al. [143] showed that a treatment with hydrogen at high temperatures could greatly enhance the performance of $\mathrm{Pd} / \mathrm{ZnO}$ catalyst. During this hydrogen-rich atmosphere, a reductive metal-support interaction occurred and a PdZn intermetallic compound was formed (Figure 11a) on the $\mathrm{Pd} / \mathrm{ZnO}$ catalyst. The positive effect on the selectivity of the SRM reaction was attributed to the presence of this PdZn alloy. Besides $\mathrm{ZnO}$, Iwasa et al. [144] studied various supports, namely, $\mathrm{Ga}_{2} \mathrm{O}_{3}$, and $\mathrm{In}_{2} \mathrm{O}_{3}$ for Pd-based catalysts. The aforementioned supports could lead to the formation of PdGa and PdIn alloy, respectively, but the performance of $\mathrm{Pd} / \mathrm{Ga}_{2} \mathrm{O}_{3}$ and $\mathrm{Pd} / \mathrm{In}_{2} \mathrm{O}_{3}$ was outnumbered by the $\mathrm{Pd} / \mathrm{ZnO}$ catalysts.

These innovative studies were followed by many research groups, making the $\mathrm{Pd} / \mathrm{ZnO}$ catalytic system the most investigated system among the group 8-10 catalysts. For instance, Dagle et al. [145] studied the effect of PdZn crystallite size on the performance of $\mathrm{Pd} / \mathrm{ZnO}$ catalysts for SRM reaction. CO selectivity was dramatically suppressed while the activity for methanol reforming followed the opposite trend, when larger PdZn crystallites were appeared in $\mathrm{Pd} / \mathrm{ZnO}$ catalysts. The effect of the preparation and pretreatment conditions on $\mathrm{Pd} / \mathrm{ZnO}$ catalysts was studied by Chin et al. [146]. The physicochemical characteristics of $\mathrm{ZnO}$ could be altered by the utilization of a highly acidic aqueous precursor $\left(\mathrm{Pd}\left(\mathrm{NO}_{3}\right)_{2}\right)$ during the preparation step (preparation method: wet impregnation). Ranganathan et al. [147] prepared a series of $\mathrm{Pd} / \mathrm{ZnO}$ and $\mathrm{Pd} / \mathrm{CeO}_{2}$ catalysts for the SRM reaction. $\mathrm{Pd} / \mathrm{ZnO}$ catalysts presented lower SRM rates but their selectivity towards $\mathrm{CO}_{2}$ was higher than the one of $\mathrm{Pd} / \mathrm{CeO}_{2}$ catalysts. Through physicochemical characterization, 
it was proposed that the conversion of formate intermediates to $\mathrm{CO}_{2}$ was favored in the $\mathrm{ZnO}$ supported catalysts due to the presence of higher density acidic sites, whereas the presence of basic sites in the $\mathrm{CeO}_{2}$ supported catalysts favored the production of $\mathrm{CO}$.

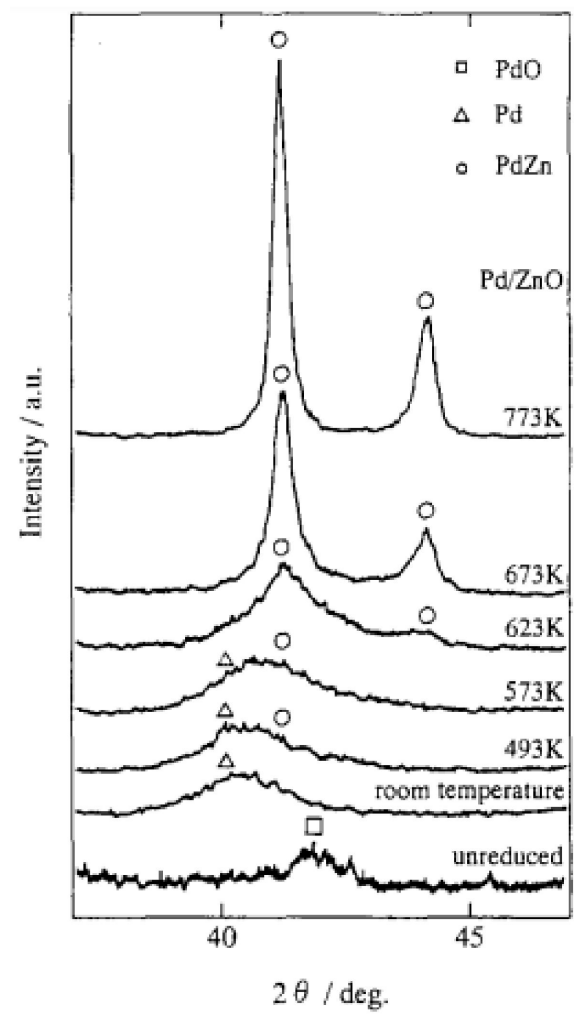

(a)

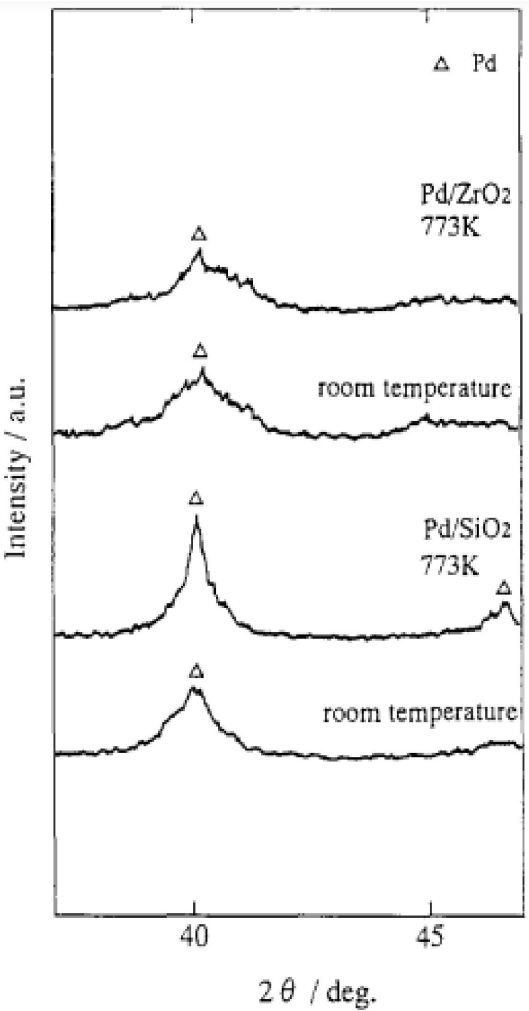

(b)

Figure 11. X-ray diffractogram of 10 wt.\% Pd on: (a) $\mathrm{ZnO}$; (b) $\mathrm{ZrO}_{2}$ and $\mathrm{SiO}_{2}$, respectively. The temperatures of reducing treatment are given in each figure. There is no evidence of $\mathrm{PdZn}$ alloy for $\mathrm{Pd} / \mathrm{ZrO}_{2}$ and $\mathrm{Pd} / \mathrm{SiO}_{2}$ catalysts. (Adapted from [143], copyright 1995, Elsevier.)

Xia et al. [136] developed a $\mathrm{Pd} / \mathrm{ZnO}$ catalyst supported onto a high surface $\mathrm{Al}_{2} \mathrm{O}_{3}$. The $\mathrm{Pd}-\mathrm{ZnO} / \mathrm{Al}_{2} \mathrm{O}_{3}$ catalyst exhibited similar activity and selectivity as on a conventional $\mathrm{Cu}$-based catalyst at $220^{\circ} \mathrm{C}$. Conant et al. [148] reported that the $\mathrm{Pd} / \mathrm{ZnO} / \mathrm{Al}_{2} \mathrm{O}_{3}$ catalysts had better long-term stability towards the SRM reaction as compared with commercial $\mathrm{Cu} / \mathrm{ZnO} / \mathrm{Al}_{2} \mathrm{O}_{3}$ catalyst. Interestingly, the regeneration of Pd-based catalyst could easily take place by oxidation in air at $420^{\circ} \mathrm{C}$, followed by re-exposure to reaction conditions at $250^{\circ} \mathrm{C}$. Concerning the commercial Cu-based catalyst, its activity could not be re-achieved after oxidation.

\subsubsection{Pt-Based Catalysts}

Pt-based catalysts were studied as an alternative substitute of Pd-based counterparts. Iwasa et al. [137] studied the performance of Pt-based catalysts supported on different oxide supports. As in the case of Pd-based catalysts, the alloys of PtZn, PtIn, and PtGa could be formed under reducing conditions. Among them, the PtZn alloy seemed to favor the performance of $\mathrm{Pt} / \mathrm{ZnO}$ catalysts, but its conversion was almost $30 \%$ lower than that of $\mathrm{Pd} / \mathrm{ZnO}$ catalyst. Avgouropoulos et al. [149] studied the performance of $\mathrm{Pt} / \mathrm{CeO}_{2}$ and $\mathrm{Pd} / \mathrm{CeO}_{2}$ catalysts synthesized via urea-combustion synthesis, for the SRM reaction. The results showed that the Pd-based catalyst was more active than $\mathrm{Pt} / \mathrm{CeO}_{2}$ catalyst.

However, there were cases where Pt-based catalysts presented better catalytic behavior than Pd-based catalysts. For example, Kolb et al. [150] prepared novel Pd/ $\mathrm{In}_{2} \mathrm{O}_{3} / \mathrm{Al}_{2} \mathrm{O}_{3}$ and $\mathrm{Pt} / \mathrm{In}_{2} \mathrm{O}_{3} / \mathrm{Al}_{2} \mathrm{O}_{3}$ for the SRM reaction. The results from this study indicated that 
the $\mathrm{Pt} / \mathrm{In}_{2} \mathrm{O}_{3} / \mathrm{Al}_{2} \mathrm{O}_{3}$ catalyst was more active than the Pd-based counterpart, and its $\mathrm{CO}$ selectivity was moderate compared with the Pd-based catalyst. The interactions between $\mathrm{Pt}$ and In seemed to play an important role behind this catalytic behavior, as a PtIn alloy was considered to be formed due to such kind of interactions. Barbosa et al. [151] studied the surface state of a Pt/ $\mathrm{In}_{2} \mathrm{O}_{3} / \mathrm{Al}_{2} \mathrm{O}_{3}$ catalyst under methanol reforming conditions. The low $\mathrm{CO}$ selectivity was attributed to the higher surface concentration of indium, a characteristic feature that was ascribed to the surface modification of support acidity by indium and/or the formation of PtIn intermetallic compound. The effect of $\mathrm{Al}_{2} \mathrm{O}_{3}$ and $\mathrm{CeO}_{2}$ supporting the preparation of ternary $\mathrm{Pt} / \mathrm{In}_{2} \mathrm{O}_{3}$-based catalysts for hydrogen production through the SRM reaction was investigated by Liu et al. [38]. The $\mathrm{Pt} / \mathrm{In}_{2} \mathrm{O}_{3} / \mathrm{CeO}_{2}$ catalyst illustrated almost complete methanol conversion with low $\mathrm{CO}$ selectivity, without a pretreatment step, at $325{ }^{\circ} \mathrm{C}$. The utilization of various physicochemical techniques showed that the support played a significant role in metal dispersion and strong metal-support interactions.

Molybdenum carbide was recently used for methanol reforming reactions due to its high thermal stability $[138,152,153]$. Ma et al. [152] found that the Pt doping onto molybdenum catalysts resulted in the formation of a highly active catalyst, achieving $100 \%$ methanol conversion at temperatures as low as $200{ }^{\circ} \mathrm{C}$. The formation of $\alpha-\mathrm{MoC}_{1-\mathrm{x}}$ phase indicated the reason behind this extraordinary performance (Figure 12 illustrates the proposed reaction pathway). This phase increased in concentration as the Pt loading followed the same trend. Trying to enhance the performance of the aforementioned system Cai et al. [138] inserted small amounts of $\mathrm{Zn}$ into the $\mathrm{Pt} / \mathrm{MoC}$ catalyst. The formation of $\alpha-\mathrm{MoC}_{1-\mathrm{x}}$ phase was facilitated, and the dispersion of $\mathrm{Pt}$ species and the interaction between $\alpha-\mathrm{MoC}_{1-\mathrm{x}}$ and $\mathrm{Pt}$ sites was significantly enhanced. This promotional effect was also illustrated in the performance of the catalyst for the SRM reaction, achieving high activity and stability at $120^{\circ} \mathrm{C}$. This new class of catalysts presented a new pathway for producing high purity hydrogen streams through the SRM reaction at temperatures lower than $200^{\circ} \mathrm{C}$.

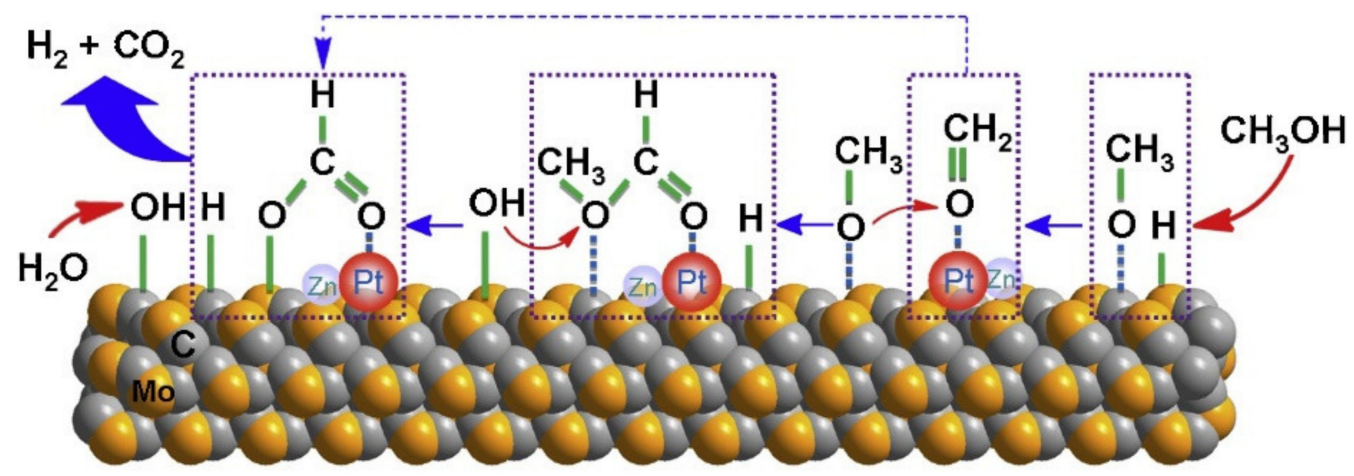

Figure 12. Proposed reaction pathway for methanol steam reforming performed on $0.5 \mathrm{Zn}-\mathrm{Pt} / \mathrm{MoC}$ catalyst. (Adapted from [138], copyright 2020, Elsevier.)

\subsubsection{Reaction Mechanism}

The reaction mechanism of the SRM reaction over group 8-10-based catalysts was developed in a different way as compared with the copper-based catalysts [154]. It was reported that the SRM reaction for this type of catalysts involved the MD reaction and a process according to the above pathway: Methanol was dehydrogenated to formaldehyde and then the latter was decomposed to $\mathrm{CO}$ and $\mathrm{H}_{2}$. Following this step, $\mathrm{CO}$ reacted with $\mathrm{H}_{2} \mathrm{O}$ (WGS reaction) to produce $\mathrm{CO}_{2}$ and $\mathrm{H}_{2}$. However, similar studies from Iwasa et al. [138,155], reported that for $\mathrm{Pd} / \mathrm{ZnO}$ catalysts, the reaction followed a mechanism similar to Cu-based catalysts (see Equations (9)-(11)) due to the presence of PdZn alloy. It was established that different species of aldehyde were adsorbed in $\mathrm{Cu}$-based and group 8-10 catalysts: $\eta^{1}(\mathrm{O})$-structure and $\eta^{2}(\mathrm{C}, \mathrm{O})$-structure, respectively. The difference between these structures was that the molecular identity of $\mathrm{HCHO}$ was preserved in the first category and desorbed without decomposition, while in the second category, the 
opposite trend was observed. Over Pd alloys, the formaldehyde species formed during the reaction were in the $\eta^{1}(\mathrm{O})$-structure and for this reason, the reaction followed the $\mathrm{Cu}$-based pathway. The high catalytic performance of PdZn alloys for the SRM reaction was attributed to the presence of $\mathrm{HCHO}$ intermediates in the $\eta^{1}(\mathrm{O})$-structure, as proposed by Iwasa and Takezawa [138].

\section{Coupling of Methanol Reformer with HT-PEMFCs}

PEMFCs cover a wide range of mobile, portable, and stationary applications [8]. Comparing the types of PEMFCs, the LT-PEMFCs demand high purity of hydrogen in order to avoid CO poisoning. The Pt-based electrocatalyst which is commonly used in this system has high affinity for $\mathrm{CO}$ and the latter is strongly adsorbed on the surface of $\mathrm{Pt}$ electrocatalyst, resulting in severe deactivation and rapid decrease in its performance [6]. On the other hand, PEMFCs, which operate at higher temperatures are not affected by these problems as the higher operating temperature increases the $\mathrm{CO}$ tolerance at concentration levels even higher than $3 \%$ (current densities: up to $0.8 \mathrm{~A} / \mathrm{cm}^{2}$ at $200{ }^{\circ} \mathrm{C}$ ). Consequently, the utilization of a hydrogen-rich reformate from various hydrocarbons or alcohols such as methanol is allowed, and in this way, the advantages of transportation and storage of a liquid fuel are implemented [156]. The main characteristics of LT-PEMFCs and HT-PEMFCs are reviewed in Table 5.

Table 5. Main characteristics of LT-PEMFCs and HT-PEMFCs.

\begin{tabular}{|c|c|c|}
\hline & LT-PEMFCs & HT-PEMFCs \\
\hline Operating temperature $\left({ }^{\circ} \mathrm{C}\right)$ & $60-80$ & $\geq 160$ \\
\hline Fuel & High purity $\mathrm{H}_{2}$ & Hydrogen-rich reformate \\
\hline Tolerance in $\mathrm{CO}$ & $<10$ ppm & $\leq 3.0 \%$ \\
\hline Infrastructure & Hydrogen station $\rightarrow$ high cost & Existing petrol station \\
\hline Fuel Cell system & Water and heat management is required & Complicated thermal management \\
\hline Operation & Quick start-up and shutdown & Slow start-up and shutdown \\
\hline
\end{tabular}

The coupling of the SRM process with the HT-PEMFCs has been widely developed among the years as a promising technology for clean energy production and especially for on-board applications $[10,11,50,157,158]$. The overall efficiency can be enhanced by more than ten percentage by the simultaneous operation of methanol reformer unit and the fuel cell, as stated by Lotric et al. [51]. In the next lines, some effort has taken place in order to review some of the most significant results regarding the methanol reformed HT-PEMFC systems. Pan et al. [49] reported that the heat integration between a HT-PEMFC and a methanol reformer (catalyst pellets packed in the flowfield channels) could improve the overall efficiency of the system, so they developed a reformed methanol HT-PEMFC system that operated at $200^{\circ} \mathrm{C}$. As shown in Figure 13, the reformed HT-PEMFC system consisted of a methanol reformer (catalyst: $\mathrm{Cu} / \mathrm{ZnO} / \mathrm{Al}_{2} \mathrm{O}_{3}$ ), which was in direct thermal contact with a two-cell stack based on PA/PBI membranes. The experimental results showed that the methanol reformer could achieve nearly $100 \%$ methanol conversion at $200{ }^{\circ} \mathrm{C}$, while the concentration of $\mathrm{CO}$ did not exceed the $0.2 \mathrm{vol} \%$. At the same operating temperature, the fuel cell could effectively operate, tolerating low concentrations of $\mathrm{CO}$.

The need for additional heat exchangers and separate methanol reformer units can be minimized through the innovative concept of internal reforming methanol fuel cell (IRMFC). The core of this idea is the direct incorporation of methanol reformer into the anode compartment of a HT-PEMFC, as the reforming catalyst layer is attached the surface of the anode of the fuel cell (Figure 14) [10,48,52,157,159]. Avgouropoulos et al. [157] proposed an IRMFC system, which mainly consisted of the following: (a) a $\mathrm{H}_{3} \mathrm{PO}_{4}$-imbibed polymer electrolyte based on aromatic polyether-bearing pyridine units, able to operate at $200{ }^{\circ} \mathrm{C}$; and (ii) a combustion-synthesized $\mathrm{CuMnO}_{\mathrm{x}}$ methanol reforming catalyst supported on copper foam active at $200^{\circ} \mathrm{C}$ with zero $\mathrm{CO}$ emissions. The performance of IRMFC system was able to remain stable for more than $72 \mathrm{~h}$, showing that the IRMFC concept is a promising 
electrochemical technology. In an effort to further promote the performance of the IRMFC system, Avgouropoulos et al. [160] adopted the CuMnOx combustion-synthesized catalyst with a small amount of $\mathrm{Al}_{2} \mathrm{O}_{3}$, resulting in a highly active catalyst for the SRM reaction. The $\mathrm{CuMnAlO} \mathrm{x}_{\mathrm{x}}$ catalyst was successfully supported on the surface of a metallic copper foam and incorporated into the anode of a HT-PEMFC. Moreover, the poisoning of the methanol reformer from $\mathrm{H}_{3} \mathrm{PO}_{4}$ was prohibited by placing an additional plate between the reformer and the anode electrocatalyst layer. Methanol conversions higher than $95 \%$ were achieved, with stable operation with time, demonstrating the functionality of IRMFC. Papavasiliou et al. [159] prepared a highly active methanol reformer by depositing a commercial copper-based catalyst $(\mathrm{CuZnAlO}$, HiFuel R120) onto the gas diffusion layer of a carbon paper via a vacuum table technique. The resulting reformer was placed into the anode compartment of an IRMFC, and a set of start-up/shut-down cycles was conducted at $210{ }^{\circ} \mathrm{C}$, in order to test its activity and stability. During the first $100 \mathrm{~h}$ under reaction conditions, the reformer illustrated extraordinary stability. However, a decrease in methanol conversion was observed (10-15\%) afterwards, which is typical for copper-based catalysts. From in situ XRD and XPS measurements under similar reaction conditions, it indicated that the reduced state of the active phase can be protected from particle's sintering via controlled passivation during start-up/shut-down cycles. Following this study, the concept of the double methanol reformer arrangement was established by Papavasiliou et al. [48]. The double methanol reformer arrangement (Figure 15) was developed in order to increase the methanol conversion and thus to minimize the membrane electrode assembly poisoning from unreacted methanol [161]. According to the aforementioned concept, two layers of methanol reformers were separated with a thin conductive gasket allowing the exit of the first layer to be the inlet of the second layer, thus increasing the catalytic bed in length and not in thickness. The experimental results showed that the methanol conversion was higher than $95 \%$, while a decrease in CO content was illustrated (from $4500 \mathrm{ppm}$ to $2100 \mathrm{ppm}$ ) after $450 \mathrm{~h}$ of operation.

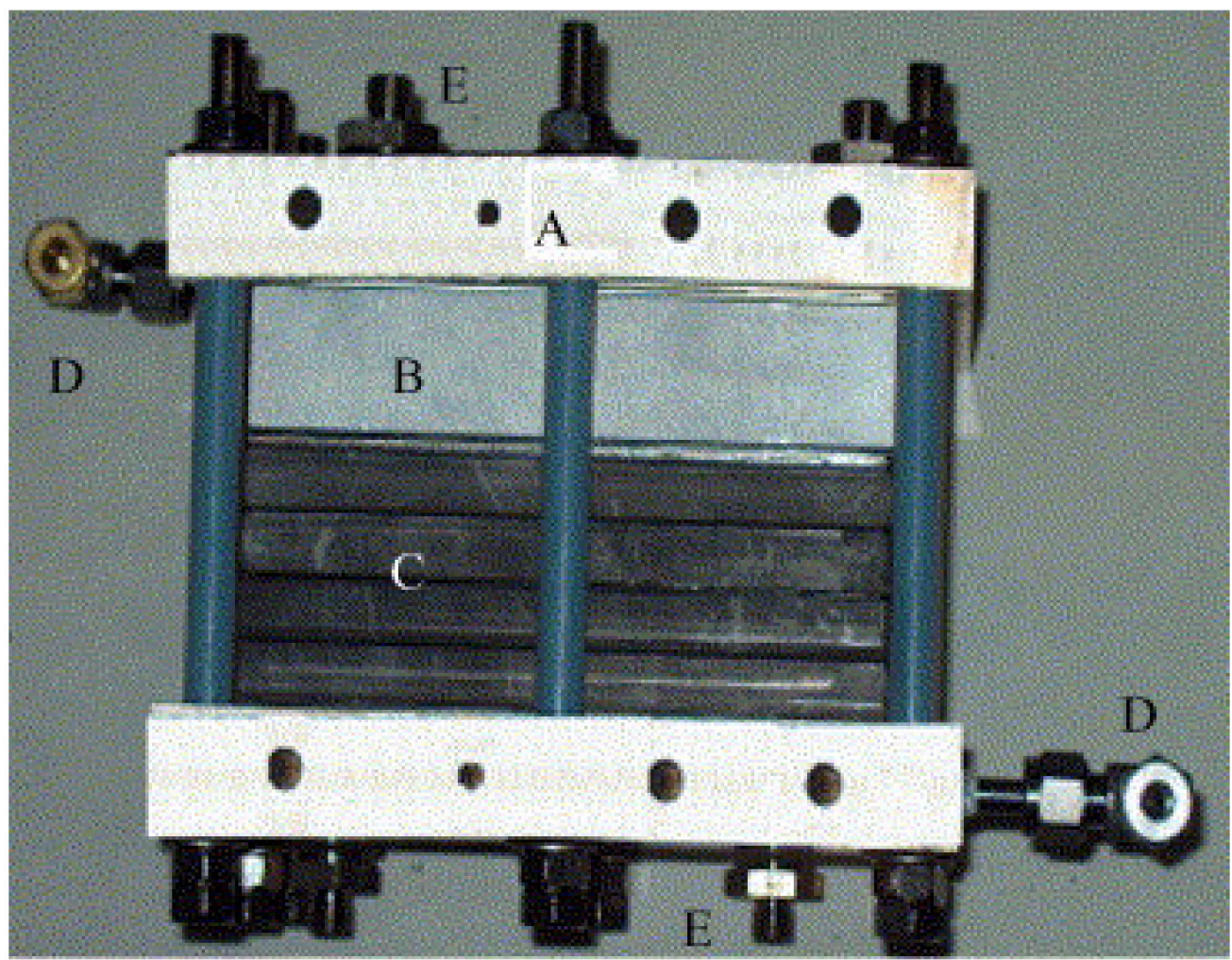

Figure 13. A two-cell stack with an integrated methanol reformer: (A) End plates with heating elements; (B) integrated methanol reformer; (C) PBI cells; (D) fuel inlet and outlet; (E) oxidant inlet and outlet. (Adapted from [49], copyright 2005, Elsevier). 


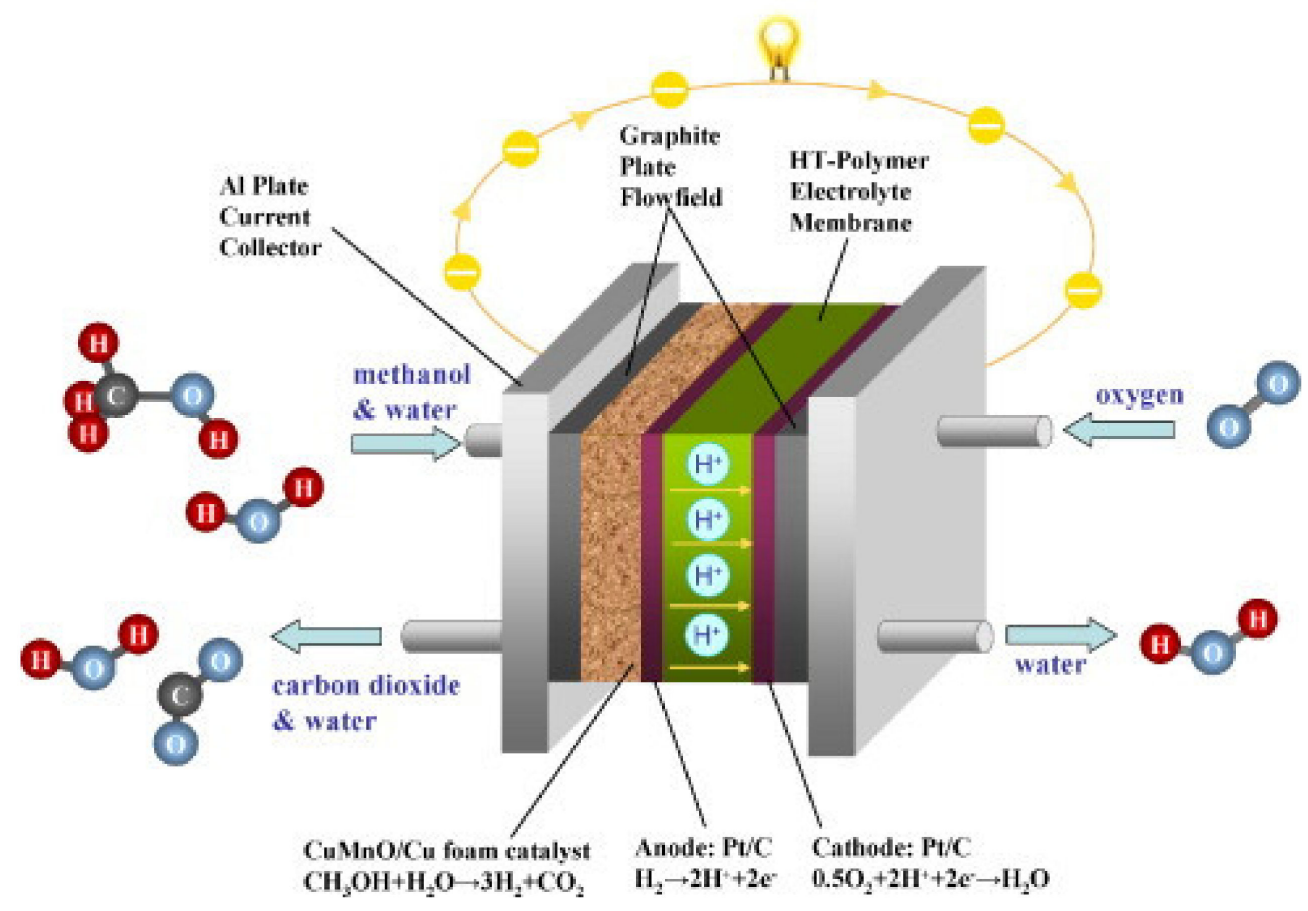

Figure 14. The IRMFC concept. (Adapted from [157], copyright 2009, Elsevier.)

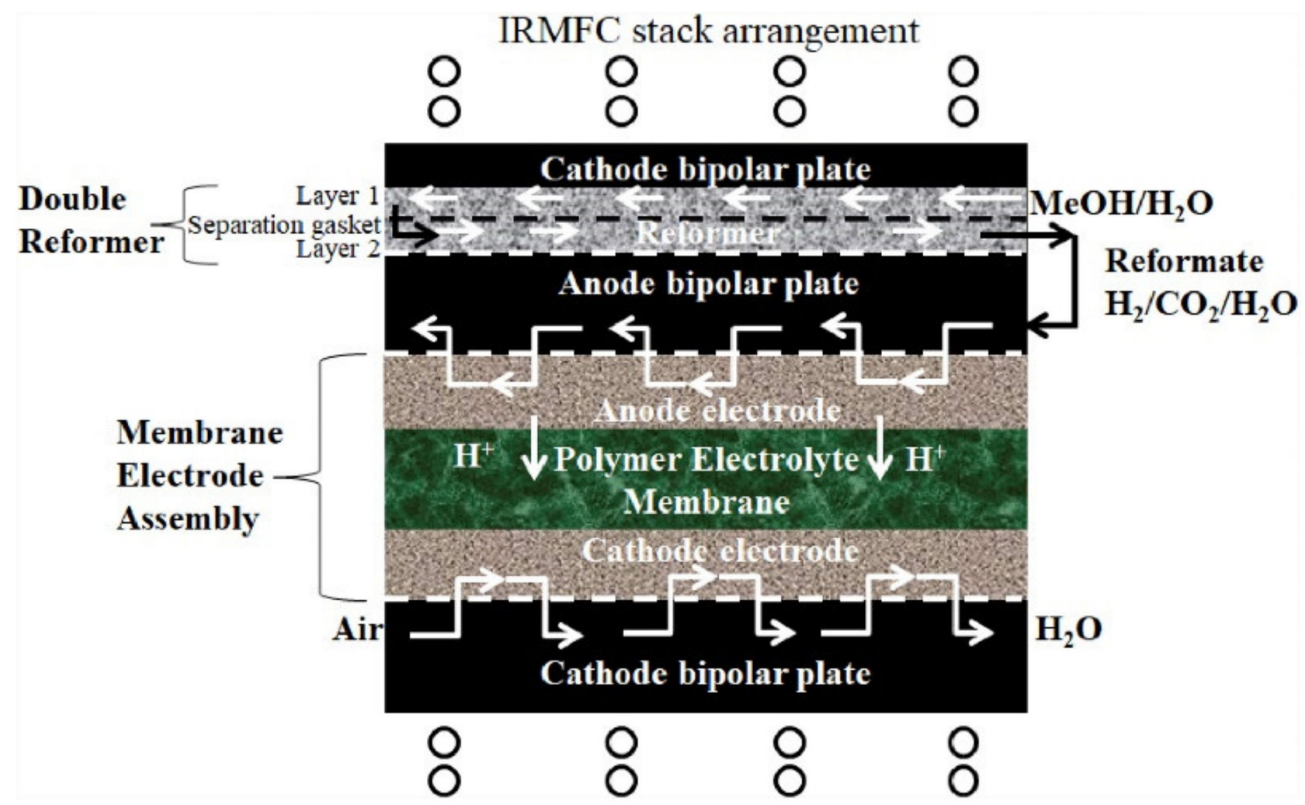

Figure 15. IRMFC configuration, employing the double methanol reformer arrangement. (Adapted from [48], copyright 2019, Elsevier.)

The concept of the reformed methanol fuel cell system was investigated both experimentally and theoretically by Lotrič et al. [51]. A novel $\mathrm{CuZnGaO}_{\mathbf{x}}$ catalysts was prepared via coprecipitation method. Through catalytic studies, it was illustrated that complete methanol conversion was achievable at $200{ }^{\circ} \mathrm{C}$ with the production of a hydrogen-rich gas stream. The theoretical data showed that the integration of the methanol reformer with HTPEM stack is highly feasible. Based on experimental results, the self-sustained working point was achieved at a current density of $0.8 \mathrm{~A} / \mathrm{cm}^{2}$, power output of $8.5 \mathrm{~W}$, methanol conversion of $98.5 \%$, and electric efficiency of $21.7 \%$. These results clearly indicated that the attainment of high methanol conversions at high current densities could be possible. 
At high current densities, the methanol reformed fuel cell stack is capable of producing the same power output with smaller number of cells, but also a more compact fuel cell unit is created. It is important to mention that the electric efficiency of the system could be also enhanced by the implementation of a catalytic combustor to the anode off-gas stream.

Ribeirinha et al. [50] developed a novel bipolar plate made of aluminum gold plate featuring the fuel cell anode flow field in one side and the reformer flow field on the other for an integrated reformed methanol HT-PEMFC system. Extraordinary performance was exhibited by this system at $180{ }^{\circ} \mathrm{C}$, indicating a small degradation rate of ca. $100 \mu \mathrm{V} / \mathrm{h}$. In another work from Ribeirinha et al. [162] a bipolar plate from poly(p-phenylene sulfide) (PPS) was prepared (Figure 16). With the integrating system operating at $180{ }^{\circ} \mathrm{C}$, high current densities $\left(>0.5 \mathrm{~A} \mathrm{~cm}^{2}\right.$ ) were reported. Moreover, the fuel cell illustrated stable performance for $100 \mathrm{~h}$ at $0.3 \mathrm{~A} \mathrm{~cm}^{2}$, exhibiting methanol conversion higher than $90 \%$.

a)

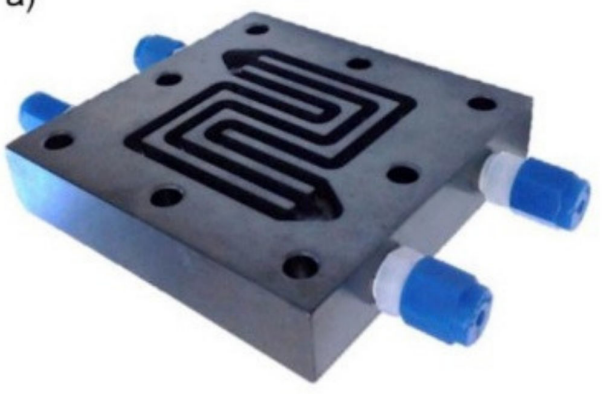

b)

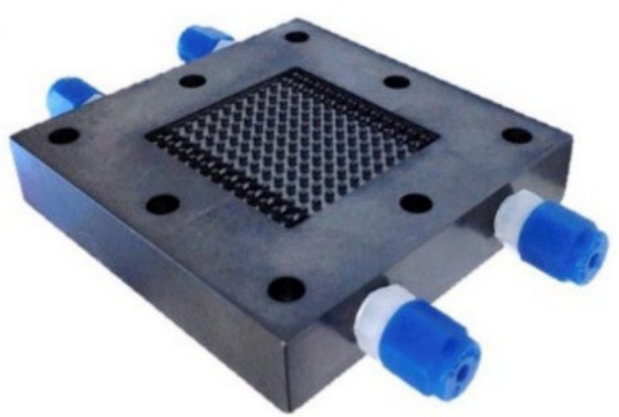

Figure 16. Bipolar plate made from PPS; (a) Reformer side, (b) Fuel cell side. (Adapted from [162], copyright 2017, Elsevier.)

\section{Conclusions}

As the world marches in the 21st century, the need for clean energy production is imperative due to increasing amounts of greenhouse gas emissions and the pollution of environment. Fuel cells can bring a tremendous positive impact in this action and the utilization of reformed hydrogen-rich fuels for HT-PEMFCs operation can decrease the overall costs.

Methanol is an attractive fuel which can be easily reformed and provide hydrogen-rich gas streams. Among the different methanol reforming processes, the steam reforming of methanol results in a reformate with the highest content in hydrogen and the lowest concentration in CO. The SRM reaction is less limited by thermodynamic rules but can be highly adjusted if the reforming catalyst is properly synthesized.

In this review, the copper-based catalysts and the group 8-10 catalysts are discussed. For copper-based catalysts, the interaction between $\mathrm{Cu}$ and $\mathrm{ZnO}$ is greatly important, and the utilization of different promoters and preparation methods can increase and/or decrease the catalytic behavior for the SRM reaction. Special reference shall be given to $\mathrm{Cu} / \mathrm{ZnO} / \mathrm{Ga}_{2} \mathrm{O}_{3}$ catalysts which can effectively convert methanol to hydrogen at low temperatures. In the second category, the $\mathrm{Pd} / \mathrm{ZnO}$ catalysts and the alloys seem to play an important role, which can be formed during pretreatment steps. According to the related literature, the selectivity of SRM is anomalously enhanced by the presence of such alloys.

A mechanism that employs the methyl formate intermediate seems to be credible among the $\mathrm{Cu}$-based catalysts, while for group 8-10 catalysts the mechanism for interpreting the reaction pathway depends on the presence or absence of intermetallic compounds; for instance, for metallic Pd, the reaction proceeds through methanol decomposition reaction while for PdZn alloy through a mechanism similar to $\mathrm{Cu}$-based catalysts.

The integration of methanol reformer into a HT-PEMFC can increase the overall efficiency of the system, reaching one step closer into clean energy production for onboard and stationary applications. However, the necessary condition of obtaining the 
same operating temperature between the reforming and the fuel cell unit should be carefully verified.

Author Contributions: Supervision, Conceptualization, and Writing-Review and Editing, G.A.; writing—review and editing, J.P.; Writing-Original Draft Preparation, K.K. All authors have read and agreed to the published version of the manuscript.

Funding: This work was financed by the European Regional Development Fund of the European Union and Greek national funds through the Operational Program Competitiveness, Entrepreneurship, and Innovation, under the call "Bilateral and Multilateral RTD cooperation between Greece and China" (project code: T1EDKI-00365). This work was also supported by the Hellenic Foundation for Research and Innovation (H.F.R.I.) under the "2nd Call for H.F.R.I. Research Projects to support Post-Doctoral Researchers" (Project Number: 1013).

Institutional Review Board Statement: Not applicable.

Informed Consent Statement: Not applicable.

Data Availability Statement: Not applicable.

Conflicts of Interest: The authors declare no conflict of interest.

\section{References}

1. Shiva Kumar, S.; Himabindu, V. Hydrogen Production by PEM Water Electrolysis-A Review. Mater. Sci. Energy Technol. 2019, 2, 442-454. [CrossRef]

2. Ranjekar, A.M.; Yadav, G.D. Steam Reforming of Methanol for Hydrogen Production: A Critical Analysis of Catalysis, Processes, and Scope. Ind. Eng. Chem. Res. 2021, 60, 89-113. [CrossRef]

3. Höök, M.; Tang, X. Depletion of Fossil Fuels and Anthropogenic Climate Change-A Review. Energy Policy 2013, 52, 797-809. [CrossRef]

4. Baidya, S.; Nandi, C. Green energy generation using renewable energy technologies. In Advances in Greener Energy Technologies; Green Energy and Technology; Bhoi, A.K., Sherpa, K.S., Kalam, A., Chae, G.-S., Eds.; Springer: Singapore, 2020 ; pp. $259-276$. ISBN 9789811542466.

5. Rogelj, J.; Huppmann, D.; Krey, V.; Riahi, K.; Clarke, L.; Gidden, M.; Nicholls, Z.; Meinshausen, M. A New Scenario Logic for the Paris Agreement Long-Term Temperature Goal. Nature 2019, 573, 357-363. [CrossRef]

6. Chandan, A.; Hattenberger, M.; El-kharouf, A.; Du, S.; Dhir, A.; Self, V.; Pollet, B.G.; Ingram, A.; Bujalski, W. High Temperature (HT) Polymer Electrolyte Membrane Fuel Cells (PEMFC)—A Review. J. Power Sources 2013, 231, 264-278. [CrossRef]

7. Kraytsberg, A.; Ein-Eli, Y. Review of Advanced Materials for Proton Exchange Membrane Fuel Cells. Energy Fuels 2014, 28, 7303-7330. [CrossRef]

8. Rosli, R.E.; Sulong, A.B.; Daud, W.R.W.; Zulkifley, M.A.; Husaini, T.; Rosli, M.I.; Majlan, E.H.; Haque, M.A. A Review of High-Temperature Proton Exchange Membrane Fuel Cell (HT-PEMFC) System. Int. J. Hydrogen Energy 2017, 42, 9293-9314. [CrossRef]

9. Choi, M.; Kim, M.; Sohn, Y.-J.; Kim, S.-G. Development of Preheating Methodology for a 5 KW HT-PEMFC System. Int. J. Hydrogen Energy 2021. [CrossRef]

10. Zhang, J.; Xiang, Y.; Lu, S.; Jiang, S.P. High Temperature Polymer Electrolyte Membrane Fuel Cells for Integrated Fuel CellMethanol Reformer Power Systems: A Critical Review. Adv. Sustain. Syst. 2018, 2, 1700184. [CrossRef]

11. Herdem, M.S.; Sinaki, M.Y.; Farhad, S.; Hamdullahpur, F. An Overview of the Methanol Reforming Process: Comparison of Fuels, Catalysts, Reformers, and Systems. Int. J. Energy Res. 2019, 43, 5076-5105. [CrossRef]

12. Aicher, T.; Lenz, B.; Gschnell, F.; Groos, U.; Federici, F.; Caprile, L.; Parodi, L. Fuel Processors for Fuel Cell APU Applications. J. Power Sources 2006, 154, 503-508. [CrossRef]

13. LeValley, T.L.; Richard, A.R.; Fan, M. The Progress in Water Gas Shift and Steam Reforming Hydrogen Production TechnologiesA Review. Int. J. Hydrogen Energy 2014, 39, 16983-17000. [CrossRef]

14. Tarhan, C.; Çil, M.A. A Study on Hydrogen, the Clean Energy of the Future: Hydrogen Storage Methods. J. Energy Storage 2021, 40, 102676. [CrossRef]

15. Kundu, A.; Shul, Y.G.; Kim, D.H. Chapter seven-Methanol reforming processes. In Advances in Fuel Cells; Zhao, T.S., Kreuer, K.-D., Van Nguyen, T., Eds.; Advances in Fuel Cell; Elsevier Science: Amsterdam, The Netherlands, 2007; Volume 1, pp. 419-472.

16. Damle, A.S. Hydrogen Production by Reforming of Liquid Hydrocarbons in a Membrane Reactor for Portable Power GenerationExperimental Studies. J. Power Sources 2009, 186, 167-177. [CrossRef]

17. Sengodan, S.; Lan, R.; Humphreys, J.; Du, D.; Xu, W.; Wang, H.; Tao, S. Advances in Reforming and Partial Oxidation of Hydrocarbons for Hydrogen Production and Fuel Cell Applications. Renew. Sustain. Energy Rev. 2018, 82, 761-780. [CrossRef]

18. Sá, S.; Silva, H.; Brandão, L.; Sousa, J.M.; Mendes, A. Catalysts for Methanol Steam Reforming-A Review. Appl. Catal. B Environ. 2010, 99, 43-57. [CrossRef] 
19. Behrens, M.; Armbrüster, M. Methanol steam reforming. In Catalysis for Alternative Energy Generation; Guczi, L., Erdôhelyi, A., Eds.; Springer: New York, NY, USA, 2012; pp. 175-235. ISBN 978-1-4614-0344-9.

20. Xu, X.; Shuai, K.; Xu, B. Review on Copper and Palladium Based Catalysts for Methanol Steam Reforming to Produce Hydrogen. Catalysts 2017, 7, 183. [CrossRef]

21. Dittmar, B.; Behrens, A.; Schödel, N.; Rüttinger, M.; Franco, T.; Straczewski, G.; Dittmeyer, R. Methane Steam Reforming Operation and Thermal Stability of New Porous Metal Supported Tubular Palladium Composite Membranes. Int. J. Hydrogen Energy 2013, 38, 8759-8771. [CrossRef]

22. Wu, Y.; Pei, C.; Tian, H.; Liu, T.; Zhang, X.; Chen, S.; Xiao, Q.; Wang, X.; Gong, J. Role of Fe Species of Ni-Based Catalysts for Efficient Low-Temperature Ethanol Steam Reforming. JACS Au 2021, 1, 1459-1470. [CrossRef]

23. Meunier, N.; Chauvy, R.; Mouhoubi, S.; Thomas, D.; De Weireld, G. Alternative Production of Methanol from Industrial $\mathrm{CO}_{2}$. Renew. Energy 2020, 146, 1192-1203. [CrossRef]

24. Trop, P.; Anicic, B.; Goricanec, D. Production of Methanol from a Mixture of Torrefied Biomass and Coal. Energy 2014, 77, 125-132. [CrossRef]

25. Galindo Cifre, P.; Badr, O. Renewable Hydrogen Utilisation for the Production of Methanol. Energy Convers. Manag. 2007, 48, 519-527. [CrossRef]

26. Yong, S.T.; Ooi, C.W.; Chai, S.P.; Wu, X.S. Review of Methanol Reforming-Cu-Based Catalysts, Surface Reaction Mechanisms, and Reaction Schemes. Int. J. Hydrogen Energy 2013, 38, 9541-9552. [CrossRef]

27. Cai, F.; Guo, Y.; Ibrahim, J.J.; Zhang, J.; Sun, Y. A Highly Active and Stable Pd/MoC Catalyst for Hydrogen Production from Methanol Decomposition. Appl. Catal. B Environ. 2021, 299, 120648. [CrossRef]

28. Araiza, D.G.; Gómez-Cortés, A.; Díaz, G. Partial Oxidation of Methanol over Copper Supported on Nanoshaped Ceria for Hydrogen Production. Catal. Today 2017, 282 Part 2, 185-194. [CrossRef]

29. Shanmugam, V.; Neuberg, S.; Zapf, R.; Pennemann, H.; Kolb, G. Hydrogen Production over Highly Active Pt Based Catalyst Coatings by Steam Reforming of Methanol: Effect of Support and Co-Support. Int. J. Hydrogen Energy 2020, 45, 1658-1670. [CrossRef]

30. Sun, Z.; Zhang, X.; Li, H.; Liu, T.; Sang, S.; Chen, S.; Duan, L.; Zeng, L.; Xiang, W.; Gong, J. Chemical Looping Oxidative Steam Reforming of Methanol: A New Pathway for Auto-Thermal Conversion. Appl. Catal. B Environ. 2020, 269, 118758. [CrossRef]

31. Bagherzadeh, S.B.; Haghighi, M. Plasma-Enhanced Comparative Hydrothermal and Coprecipitation Preparation of $\mathrm{CuO} / \mathrm{ZnO} / \mathrm{Al} 2 \mathrm{O} 3$ Nanocatalyst Used in Hydrogen Production via Methanol Steam Reforming. Energy Convers. Manag. 2017, 142, 452-465. [CrossRef]

32. Kapran, A.Y.; Orlyk, S.M. Hydrogen Production in Methanol Reforming on Modified Copper-Zinc Catalysts: A Review. Exp. Chem. 2017, 53, 1-16. [CrossRef]

33. Mateos-Pedrero, C.; Azenha, C.; Pacheco Tanaka, D.A.; Sousa, J.M.; Mendes, A. The Influence of the Support Composition on the Physicochemical and Catalytic Properties of Cu Catalysts Supported on Zirconia-Alumina for Methanol Steam Reforming. Appl. Catal. B Environ. 2020, 277, 119243. [CrossRef]

34. Patel, S.; Pant, K.K. Influence of Preparation Method on Performance of $\mathrm{Cu}(\mathrm{Zn})(\mathrm{Zr})$-Alumina Catalysts for the Hydrogen Production via Steam Reforming of Methanol. J. Porous Mater. 2006, 13, 373-378. [CrossRef]

35. Papavasiliou, J.; Paxinou, A.; Słowik, G.; Neophytides, S.; Avgouropoulos, G. Steam Reforming of Methanol over Nanostructured $\mathrm{Pt} / \mathrm{TiO}_{2}$ and $\mathrm{Pt} / \mathrm{CeO}_{2}$ Catalysts for Fuel Cell Applications. Catalysts 2018, 8, 544. [CrossRef]

36. Khani, Y.; Bahadoran, F.; Safari, N.; Soltanali, S.; Taheri, S.A. Hydrogen Production from Steam Reforming of Methanol over $\mathrm{Cu}$-Based Catalysts: The Behavior of ZnxLaxAl1-XO4 and $\mathrm{ZnO} / \mathrm{La}_{2} \mathrm{O}_{3} / \mathrm{Al}_{2} \mathrm{O}_{3}$ Lined on Cordierite Monolith Reactors. Int. J. Hydrogen Energy 2019, 44, 11824-11837. [CrossRef]

37. Kim, W.; Mohaideen, K.K.; Seo, D.J.; Yoon, W.L. Methanol-Steam Reforming Reaction over Cu-Al-Based Catalysts Derived from Layered Double Hydroxides. Int. J. Hydrogen Energy 2017, 42, 2081-2087. [CrossRef]

38. Liu, X.; Men, Y.; Wang, J.; He, R.; Wang, Y. Remarkable Support Effect on the Reactivity of Pt/ $\mathrm{In}_{2} \mathrm{O}_{3} / \mathrm{MOx}$ Catalysts for Methanol Steam Reforming. J. Power Sources 2017, 364, 341-350. [CrossRef]

39. Udani, P.P.C.; Gunawardana, P.V.D.S.; Lee, H.C.; Kim, D.H. Steam Reforming and Oxidative Steam Reforming of Methanol over CuO-CeO2 Catalysts. Int. J. Hydrogen Energy 2009, 34, 7648-7655. [CrossRef]

40. Pu, Y.-C.; Li, S.-R.; Yan, S.; Huang, X.; Wang, D.; Ye, Y.-Y.; Liu, Y.-Q. An Improved Cu/ZnO Catalyst Promoted by Sc $\mathrm{O}_{3}$ for Hydrogen Production from Methanol Reforming. Fuel 2019, 241, 607-615. [CrossRef]

41. Kurtz, M.; Wilmer, H.; Genger, T.; Hinrichsen, O.; Muhler, M. Deactivation of Supported Copper Catalysts for Methanol Synthesis. Catal. Lett. 2003, 86, 77-80. [CrossRef]

42. Zhang, H.; Sun, J.; Dagle, V.L.; Halevi, B.; Datye, A.K.; Wang, Y. Influence of ZnO Facets on Pd/ZnO Catalysts for Methanol Steam Reforming. ACS Catal. 2014, 4, 2379-2386. [CrossRef]

43. Tong, W.; West, A.; Cheung, K.; Yu, K.-M.; Tsang, S.C.E. Dramatic Effects of Gallium Promotion on Methanol Steam Reforming $\mathrm{Cu}-\mathrm{ZnO}$ Catalyst for Hydrogen Production: Formation of 5 Å Copper Clusters from Cu-ZnGaOx. ACS Catal. 2013, 3, 1231-1244. [CrossRef]

44. Wang, C.; Ouyang, M.; Li, M.; Lee, S.; Flytzani-Stephanopoulos, M. Low-Coordinated Pd Catalysts Supported on Zn1Zr1Ox Composite Oxides for Selective Methanol Steam Reforming. Appl. Catal. A Gen. 2019, 580, 81-92. [CrossRef] 
45. Talkhoncheh, S.K.; Haghighi, M.; Minaei, S.; Ajamein, H.; Abdollahifar, M. Synthesis of $\mathrm{CuO} / \mathrm{ZnO} / \mathrm{Al}_{2} \mathrm{O}_{3} / \mathrm{ZrO}_{2} / \mathrm{CeO}_{2} \mathrm{Nanocat}-$ alysts via Homogeneous Precipitation and Combustion Methods Used in Methanol Steam Reforming for Fuel Cell Grade Hydrogen Production. RSC Adv. 2016, 6, 57199-57209. [CrossRef]

46. Rameshan, C.; Lorenz, H.; Armbrüster, M.; Kasatkin, I.; Klötzer, B.; Götsch, T.; Ploner, K.; Penner, S. Impregnated and CoPrecipitated $\mathrm{Pd}-\mathrm{Ga}_{2} \mathrm{O}_{3}, \mathrm{Pd}-\mathrm{In}_{2} \mathrm{O}_{3}$ and $\mathrm{Pd}-\mathrm{Ga}_{2} \mathrm{O}_{3}-\mathrm{In}_{2} \mathrm{O}_{3}$ Catalysts: Influence of the Microstructure on the $\mathrm{CO}_{2}$ Selectivity in Methanol Steam Reforming. Catal. Lett. 2018, 148, 3062-3071. [CrossRef]

47. Avgouropoulos, G.; Schlicker, S.; Schelhaas, K.-P.; Papavasiliou, J.; Papadimitriou, K.D.; Theodorakopoulou, E.; Gourdoupi, N.; Machocki, A.; Ioannides, T.; Kallitsis, J.K.; et al. Performance Evaluation of a Proof-of-Concept 70 W Internal Reforming Methanol Fuel Cell System. J. Power Sources 2016, 307, 875-882. [CrossRef]

48. Papavasiliou, J.; Schütt, C.; Kolb, G.; Neophytides, S.; Avgouropoulos, G. Technological Aspects of an Auxiliary Power Unit with Internal Reforming Methanol Fuel Cell. Int. J. Hydrogen Energy 2019, 44, 12818-12828. [CrossRef]

49. Pan, C.; He, R.; Li, Q.; Jensen, J.O.; Bjerrum, N.J.; Hjulmand, H.A.; Jensen, A.B. Integration of High Temperature PEM Fuel Cells with a Methanol Reformer. J. Power Sources 2005, 145, 392-398. [CrossRef]

50. Ribeirinha, P.; Schuller, G.; Boaventura, M.; Mendes, A. Synergetic Integration of a Methanol Steam Reforming Cell with a High Temperature Polymer Electrolyte Fuel Cell. Int. J. Hydrogen Energy 2017, 42, 13902-13912. [CrossRef]

51. Lotrič, A.; Sekavčnik, M.; Pohar, A.; Likozar, B.; Hočevar, S. Conceptual Design of an Integrated Thermally Self-Sustained Methanol Steam Reformer-High-Temperature PEM Fuel Cell Stack Manportable Power Generator. Int. J. Hydrogen Energy 2017, 42, 16700-16713. [CrossRef]

52. Papavasiliou, J.; Avgouropoulos, G.; Ioannides, T. CuMnOx Catalysts for Internal Reforming Methanol Fuel Cells: Application Aspects. Int. J. Hydrogen Energy 2012, 37, 16739-16747. [CrossRef]

53. Jing, J.; Li, L.; Chu, W.; Wei, Y.; Jiang, C. Microwave-Assisted Synthesis of High Performance Copper-Based Catalysts for Hydrogen Production from Methanol Decomposition. Int. J. Hydrogen Energy 2018, 43, 12059-12068. [CrossRef]

54. Marbán, G.; López, A.; López, I.; Valdés-Solís, T. A Highly Active, Selective and Stable Copper/Cobalt-Structured Nanocatalyst for Methanol Decomposition. Appl. Catal. B Environ. 2010, 99, 257-264. [CrossRef]

55. Manova, E.; Tsoncheva, T.; Estournès, C.; Paneva, D.; Tenchev, K.; Mitov, I.; Petrov, L. Nanosized Iron and Iron-Cobalt Spinel Oxides as Catalysts for Methanol Decomposition. Appl. Catal. A Gen. 2006, 300, 170-180. [CrossRef]

56. Mizsey, P.; Newson, E.; Truong, T.; Hottinger, P. The Kinetics of Methanol Decomposition: A Part of Autothermal Partial Oxidation to Produce Hydrogen for Fuel Cells. Appl. Catal. A Gen. 2001, 213, 233-237. [CrossRef]

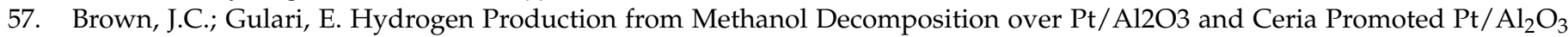
Catalysts. Catal. Commun. 2004, 5, 431-436. [CrossRef]

58. Ostroverkh, A.; Johánek, V.; Kúš, P.; Šedivá, R.; Matolín, V. Efficient Ceria-Platinum Inverse Catalyst for Partial Oxidation of Methanol. Langmuir 2016, 32, 6297-6309. [CrossRef]

59. Borup, R.; Meyers, J.; Pivovar, B.; Kim, Y.S.; Mukundan, R.; Garland, N.; Myers, D.; Wilson, M.; Garzon, F.; Wood, D.; et al Scientific Aspects of Polymer Electrolyte Fuel Cell Durability and Degradation. Chemical. Rev. 2007, 107, 3904-3951. [CrossRef]

60. Ajamein, H.; Haghighi, M.; Alaei, S. The Role of Various Fuels on Microwave-Enhanced Combustion Synthesis of $\mathrm{CuO} / \mathrm{ZnO} / \mathrm{Al}_{2} \mathrm{O}_{3}$ Nanocatalyst Used in Hydrogen Production via Methanol Steam Reforming. Energy Convers. Manag. 2017, 137, 61-73. [CrossRef]

61. Faungnawakij, K.; Kikuchi, R.; Eguchi, K. Thermodynamic Evaluation of Methanol Steam Reforming for Hydrogen Production. J. Power Sources 2006, 161, 87-94. [CrossRef]

62. Wang, J.; Chen, H.; Tian, Y.; Yao, M.; Li, Y. Thermodynamic Analysis of Hydrogen Production for Fuel Cells from Oxidative Steam Reforming of Methanol. Fuel 2012, 97, 805-811. [CrossRef]

63. Lwin, Y.; Daud, W.R.W.; Mohamad, A.B.; Yaakob, Z. Hydrogen Production from Steam-Methanol Reforming: Thermodynamic Analysis. Int. J. Hydrogen Energy 2000, 25, 47-53. [CrossRef]

64. Xing, S.; Zhao, C.; Ban, S.; Liu, Y.; Wang, H. Thermodynamic Performance Analysis of the Influence of Multi-Factor Coupling on the Methanol Steam Reforming Reaction. Int. J. Hydrogen Energy 2020, 45, 7015-7024. [CrossRef]

65. Lattner, J.R.; Harold, M.P. Autothermal Reforming of Methanol: Experiments and Modeling. Catal. Today 2007, 120, 78-89. [CrossRef]

66. Chen, W.-H.; Su, Y.-Q.; Lin, B.-J.; Kuo, J.-K.; Kuo, P.-C. Hydrogen Production from Partial Oxidation and Autothermal Reforming of Methanol from a Cold Start in Sprays. Fuel 2021, 287, 119638. [CrossRef]

67. Tang, H.-Y.; Erickson, P.; Yoon, H.C.; Liao, C.-H. Comparison of Steam and Autothermal Reforming of Methanol Using a Packed-Bed Low-Cost Copper Catalyst. Int. J. Hydrogen Energy 2009, 34, 7656-7665. [CrossRef]

68. Garcia, G.; Arriola, E.; Chen, W.-H.; De Luna, M.D. A Comprehensive Review of Hydrogen Production from Methanol Thermochemical Conversion for Sustainability. Energy 2021, 217, 119384. [CrossRef]

69. Rozovskii, A.Y.; Lin, G.I. Fundamentals of Methanol Synthesis and Decomposition. Top. Catal. 2003, 22, 137-150. [CrossRef]

70. Palo, D.R.; Dagle, R.A.; Holladay, J.D. Methanol Steam Reforming for Hydrogen Production. Chem. Rev. 2007, $107,3992-4021$. [CrossRef]

71. Butt, J. Activation, Deactivation, and Poisoning of Catalysts; Elsevier: Amsterdam, The Netherlands, 2012; ISBN 978-0-323-14086-7.

72. Spencer, M.S. The Role of Zinc Oxide in $\mathrm{Cu} / \mathrm{ZnO}$ Catalysts for Methanol Synthesis and the Water-Gas Shift Reaction. Top. Catal. 1999, 8, 259. [CrossRef] 
73. Behrens, M.; Studt, F.; Kasatkin, I.; Kühl, S.; Hävecker, M.; Abild-Pedersen, F.; Zander, S.; Girgsdies, F.; Kurr, P.; Kniep, B.-L.; et al. The Active Site of Methanol Synthesis over $\mathrm{Cu} / \mathrm{ZnO} / \mathrm{Al}_{2} \mathrm{O}_{3}$ Industrial Catalysts. Science 2012, 336, 893-897. [CrossRef]

74. Rameshan, C.; Stadlmayr, W.; Penner, S.; Lorenz, H.; Memmel, N.; Hävecker, M.; Blume, R.; Teschner, D.; Rocha, T.; Zemlyanov, D.; et al. Hydrogen Production by Methanol Steam Reforming on Copper Boosted by Zinc-Assisted Water Activation. Angew. Chem. Int. Ed. 2012, 51, 3002-3006. [CrossRef]

75. Hansen, J.B.; Højlund Nielsen, P.E. Methanol Synthesis. In Handbook of Heterogeneous Catalysis; American Cancer Society: Atlanta, GA, USA, 2008; pp. 2920-2949. ISBN 978-3-527-61004-4.

76. Grunwaldt, J.-D.; Molenbroek, A.M.; Topsøe, N.-Y.; Topsøe, H.; Clausen, B.S. In Situ Investigations of Structural Changes in $\mathrm{Cu} / \mathrm{ZnO}$ Catalysts. J. Catal. 2000, 194, 452-460. [CrossRef]

77. Kasatkin, I.; Kurr, P.; Kniep, B.; Trunschke, A.; Schlögl, R. Role of Lattice Strain and Defects in Copper Particles on the Activity of $\mathrm{Cu} / \mathrm{ZnO} / \mathrm{Al}_{2} \mathrm{O}_{3}$ Catalysts for Methanol Synthesis. Angew. Chem. Int. Ed. 2007, 46, 7324-7327. [CrossRef] [PubMed]

78. Burch, R.; Golunski, S.E.; Spencer, M.S. The Role of Copper and Zinc Oxide in Methanol Synthesis Catalysts. J. Chem. Soc. Faraday Trans. 1990, 86, 2683-2691. [CrossRef]

79. Nakamura, J.; Choi, Y.; Fujitani, T. On the Issue of the Active Site and the Role of ZnO in Cu/ZnO Methanol Synthesis Catalysts. Top. Catal. 2003, 22, 277-285. [CrossRef]

80. D'Alnoncourt, R.N.; Xia, X.; Strunk, J.; Löffler, E.; Hinrichsen, O.; Muhler, M. The Influence of Strongly Reducing Conditions on Strong Metal-Support Interactions in $\mathrm{Cu} / \mathrm{ZnO}$ Catalysts Used for Methanol Synthesis. Phys. Chem. Chem. Phys. 2006, 8, 1525-1538. [CrossRef]

81. Frank, B.; Jentoft, F.C.; Soerijanto, H.; Kröhnert, J.; Schlögl, R.; Schomäcker, R. Steam Reforming of Methanol over CopperContaining Catalysts: Influence of Support Material on Microkinetics. J. Catal. 2007, 246, 177-192. [CrossRef]

82. Twigg, M.V.; Spencer, M.S. Deactivation of Copper Metal Catalysts for Methanol Decomposition, Methanol Steam Reforming and Methanol Synthesis. Top. Catal. 2003, 22, 191-203. [CrossRef]

83. Huang, G.; Liaw, B.-J.; Jhang, C.-J.; Chen, Y.-Z. Steam Reforming of Methanol over $\mathrm{CuO} / \mathrm{ZnO} / \mathrm{CeO} 2 / \mathrm{ZrO}_{2} / \mathrm{Al}_{2} \mathrm{O}_{32} \mathrm{Catalysts}$. Appl. Catal. A Gen. 2009, 358,7-12. [CrossRef]

84. Shishido, T.; Yamamoto, Y.; Morioka, H.; Takehira, K. Production of Hydrogen from Methanol over $\mathrm{Cu} / \mathrm{ZnO}$ and $\mathrm{Cu} / \mathrm{ZnO} / \mathrm{Al}_{2} \mathrm{O}_{3}$ Catalysts Prepared by Homogeneous Precipitation: Steam Reforming and Oxidative Steam Reforming. J. Mol. Catal. A Chem. 2007, 268, 185-194. [CrossRef]

85. Matsumura, Y.; Ishibe, H. High Temperature Steam Reforming of Methanol over $\mathrm{Cu} / \mathrm{ZnO} / \mathrm{ZrO}_{2}$ Catalysts. Appl. Catal. B Environ. 2009, 91, 524-532. [CrossRef]

86. Matter, P.H.; Braden, D.J.; Ozkan, U.S. Steam Reforming of Methanol to H2 over Nonreduced Zr-Containing CuO/ZnO Catalysts. J. Catal. 2004, 223, 340-351. [CrossRef]

87. Yang, S.; Zhou, F.; Liu, Y.; Zhang, L.; Chen, Y.; Wang, H.; Tian, Y.; Zhang, C.; Liu, D. Morphology Effect of Ceria on the Performance of $\mathrm{CuO} / \mathrm{CeO} 2$ Catalysts for Hydrogen Production by Methanol Steam Reforming. Int. J. Hydrogen Energy 2019, 44, 7252-7261. [CrossRef]

88. Liu, Y.; Hayakawa, T.; Tsunoda, T.; Suzuki, K.; Hamakawa, S.; Murata, K.; Shiozaki, R.; Ishii, T.; Kumagai, M. Steam Reforming of Methanol Over $\mathrm{Cu} / \mathrm{CeO}_{2}$ Catalysts Studied in Comparison with $\mathrm{Cu} / \mathrm{ZnO}$ and $\mathrm{Cu} / \mathrm{Zn}(\mathrm{Al}) \mathrm{O}$ Catalysts. Top. Catal. 2003, 22, 205-213. [CrossRef]

89. Jones, S.D.; Hagelin-Weaver, H.E. Steam Reforming of Methanol over $\mathrm{CeO}_{2}$ - and $\mathrm{ZrO}_{2}-\mathrm{Promoted} \mathrm{Cu}-\mathrm{ZnO}$ Catalysts Supported on Nanoparticle Al2O3. Appl. Catal. B Environ. 2009, 90, 195-204. [CrossRef]

90. Matsumura, Y. Stabilization of $\mathrm{Cu} / \mathrm{ZnO} / \mathrm{ZrO}_{2}$ Catalyst for Methanol Steam Reforming to Hydrogen by Coprecipitation on Zirconia Support. J. Power Sources 2013, 238, 109-116. [CrossRef]

91. Arena, F.; Italiano, G.; Barbera, K.; Bordiga, S.; Bonura, G.; Spadaro, L.; Frusteri, F. Solid-State Interactions, Adsorption Sites and Functionality of $\mathrm{Cu}-\mathrm{ZnO} / \mathrm{ZrO}_{2}$ Catalysts in the $\mathrm{CO}_{2}$ Hydrogenation to $\mathrm{CH} 3 \mathrm{OH}$. Appl. Catal. A Gen. 2008, 350, 16-23. [CrossRef]

92. Breen, J.P.; Ross, J.R.H. Methanol Reforming for Fuel-Cell Applications: Development of Zirconia-Containing Cu-Zn-Al Catalysts. Catal. Today 1999, 51, 521-533. [CrossRef]

93. Wu, G.-S.; Mao, D.-S.; Lu, G.-Z.; Cao, Y.; Fan, K.-N. The Role of the Promoters in Cu Based Catalysts for Methanol Steam Reforming. Catal. Lett. 2009, 130, 177-184. [CrossRef]

94. Baneshi, J.; Haghighi, M.; Jodeiri, N.; Abdollahifar, M.; Ajamein, H. Urea-Nitrate Combustion Synthesis of $\mathrm{ZrO}_{2}$ and CeO $\mathrm{Doped}_{2}$ $\mathrm{CuO} / \mathrm{Al}_{2} \mathrm{O}_{3}$ Nanocatalyst Used in Steam Reforming of Biomethanol for Hydrogen Production. Ceram. Int. 2014, 40, 14177-14184. [CrossRef]

95. Minaei, S.; Haghighi, M.; Jodeiri, N.; Ajamein, H.; Abdollahifar, M. Urea-Nitrates Combustion Preparation of CeO 2 -Promoted $\mathrm{CuO} / \mathrm{ZnO} / \mathrm{Al}_{2} \mathrm{O}_{3}$ Nanocatalyst for Fuel Cell Grade Hydrogen Production via Methanol Steam Reforming. Adv. Powder Technol. 2017, 28, 842-853. [CrossRef]

96. Bagherzadeh, S.B.; Haghighi, M.; Rahemi, N. Novel Oxalate Gel Coprecipitation Synthesis of $\mathrm{ZrO}_{2}-\mathrm{CeO}_{2}-\mathrm{Promoted} \mathrm{CuO}-\mathrm{ZnO}-$ $\mathrm{Al}_{2} \mathrm{O}_{3}$ Nanocatalyst for Fuel Cell-Grade Hydrogen Production from Methanol: Influence of Ceria-Zirconia Loading. Energy Convers. Manag. 2017, 134, 88-102. [CrossRef]

97. Patel, S.; Pant, K.K. Activity and Stability Enhancement of Copper-Alumina Catalysts Using Cerium and Zinc Promoters for the Selective Production of Hydrogen via Steam Reforming of Methanol. J. Power Sources 2006, 159, 139-143. [CrossRef] 
98. Yu, K.M.K.; Tong, W.; West, A.; Cheung, K.; Li, T.; Smith, G.; Guo, Y.; Tsang, S.C.E. Non-Syngas Direct Steam Reforming of Methanol to Hydrogen and Carbon Dioxide at Low Temperature. Nat. Commun. 2012, 3, 1-7. [CrossRef]

99. Pohar, A.; Hočevar, S.; Likozar, B.; Levec, J. Synthesis and Characterization of Gallium-Promoted Copper-Ceria Catalyst and Its Application for Methanol Steam Reforming in a Packed Bed Reactor. Catal. Today 2015, 256, 358-364. [CrossRef]

100. Tong, W.; Cheung, K.; West, A.; Yu, K.-M.; Tsang, S.C.E. Direct Methanol Steam Reforming to Hydrogen over CuZnGaOx Catalysts without CO Post-Treatment: Mechanistic Considerations. Phys. Chem. Chem. Phys. 2013, 15, 7240-7248. [CrossRef]

101. Li, M.M.-J.; Zeng, Z.; Liao, F.; Hong, X.; Tsang, S.C.E. Enhanced CO2 Hydrogenation to Methanol over CuZn Nanoalloy in Ga Modified Cu/ZnO Catalysts. J. Catal. 2016, 343, 157-167. [CrossRef]

102. Li, M.M.-J.; Zheng, J.; Qu, J.; Liao, F.; Raine, E.; Kuo, W.C.H.; Su, S.S.; Po, P.; Yuan, Y.; Tsang, S.C.E. The Remarkable Activity and Stability of a Highly Dispersive Beta-Brass Cu-Zn Catalyst for the Production of Ethylene Glycol. Sci. Rep. 2016, 6, 20527. [CrossRef]

103. Li, M.M.-J.; Chen, C.; Ayvalı, T.; Suo, H.; Zheng, J.; Teixeira, I.F.; Ye, L.; Zou, H.; O'Hare, D.; Tsang, S.C.E. CO 2 Hydrogenation to Methanol over Catalysts Derived from Single Cationic Layer CuZnGa LDH Precursors. ACS Catal. 2018, 8, 4390-4401. [CrossRef]

104. Papavasiliou, J.; Avgouropoulos, G.; Ioannides, T. Steam Reforming of Methanol over Copper-Manganese Spinel Oxide Catalysts. Catal. Commun. 2005, 6, 497-501. [CrossRef]

105. Papavasiliou, J.; Avgouropoulos, G.; Ioannides, T. Combined Steam Reforming of Methanol over Cu-Mn Spinel Oxide Catalysts. J. Catal. 2007, 251, 7-20. [CrossRef]

106. Lindström, B.; Pettersson, L.J.; Govind Menon, P. Activity and Characterization of $\mathrm{Cu} / \mathrm{Zn}, \mathrm{Cu} / \mathrm{Cr}$ and $\mathrm{Cu} / \mathrm{Zr}$ on $\gamma$-Alumina for Methanol Reforming for Fuel Cell Vehicles. Appl. Catal. A Gen. 2002, 234, 111-125. [CrossRef]

107. Valdés-Solís, T.; Marbán, G.; Fuertes, A.B. Nanosized Catalysts for the Production of Hydrogen by Methanol Steam Reforming. Catal. Today 2006, 116, 354-360. [CrossRef]

108. Maiti, S.; Llorca, J.; Dominguez, M.; Colussi, S.; Trovarelli, A.; Priolkar, K.R.; Aquilanti, G.; Gayen, A. Combustion Synthesized Copper-Ion Substituted $\mathrm{FeAl}_{2} \mathrm{O}_{4}\left(\mathrm{Cu}_{0.1} \mathrm{Fe}_{0.9} \mathrm{Al}_{2} \mathrm{O}_{4}\right)$ : A Superior Catalyst for Methanol Steam Reforming Compared to Its Impregnated Analogue. J. Power Sources 2016, 304, 319-331. [CrossRef]

109. Maiti, S.; Das, D.; Pal, K.; Llorca, J.; Soler, L.; Colussi, S.; Trovarelli, A.; Priolkar, K.R.; Sarode, P.R.; Asakura, K.; et al. Methanol Steam Reforming Behavior of Sol-Gel Synthesized Nanodimensional CuxFe1- $\mathrm{XAl}_{2} \mathrm{O}_{4}$ Hercynites. Appl. Catal. A Gen. 2019, 570, 73-83. [CrossRef]

110. Jeong, H.; Kim, K.I.; Kim, T.H.; Ko, C.H.; Park, H.C.; Song, I.K. Hydrogen Production by Steam Reforming of Methanol in a Micro-Channel Reactor Coated with Cu/ZnO/ZrO2/Al2O3 Catalyst. J. Power Sources 2006, 159, 1296-1299. [CrossRef]

111. Kawamura, Y.; Yamamoto, K.; Ogura, N.; Katsumata, T.; Igarashi, A. Preparation of $\mathrm{Cu} / \mathrm{ZnO} / \mathrm{Al}_{2} \mathrm{O}_{3} \mathrm{Catalyst}_{\text {for a } \mathrm{Micro}}$ Methanol Reformer. J. Power Sources 2005, 150, 20-26. [CrossRef]

112. Zhang, L.; Pan, L.; Ni, C.; Sun, T.; Zhao, S.; Wang, S.; Wang, A.; Hu, Y. CeO $-\mathrm{ZrO}_{2}-$ Promoted CuO/ZnO Catalyst for Methanol Steam Reforming. Int. J. Hydrogen Energy 2013, 38, 4397-4406. [CrossRef]

113. Oguchi, H.; Nishiguchi, T.; Matsumoto, T.; Kanai, H.; Utani, K.; Matsumura, Y.; Imamura, S. Steam Reforming of Methanol over $\mathrm{Cu} / \mathrm{CeO} 2 / \mathrm{ZrO} 2$ Catalysts. Appl. Catal. A Gen. 2005, 281, 69-73. [CrossRef]

114. Toyir, J.; Ramírez de la Piscina, P.; Homs, N. Ga-Promoted Copper-Based Catalysts Highly Selective for Methanol Steam Reforming to Hydrogen; Relation with the Hydrogenation of $\mathrm{CO}_{2}$ to Methanol. Int. J. Hydrogen Energy 2015, 40, 11261-11266. [CrossRef]

115. Huang, X.; Ma, L.; Wainwright, M.S. The Influence of Cr, Zn and Co Additives on the Performance of Skeletal Copper Catalysts for Methanol Synthesis and Related Reactions. Appl. Catal. A Gen. 2004, 257, 235-243. [CrossRef]

116. Kuo, M.-T.; Chen, Y.-Y.; Hung, W.-Y.; Lin, S.-F.; Lin, H.-P.; Hsu, C.-H.; Shih, H.-Y.; Xie, W.-A.; Li, S.-N. Synthesis of Mesoporous $\mathrm{CuFe} /$ Silicates Catalyst for Methanol Steam Reforming. Int. J. Hydrogen Energy 2019, 44, 14416-14423. [CrossRef]

117. Yao, C.-Z.; Wang, L.-C.; Liu, Y.-M.; Wu, G.-S.; Cao, Y.; Dai, W.-L.; He, H.-Y.; Fan, K.-N. Effect of Preparation Method on the Hydrogen Production from Methanol Steam Reforming over Binary Cu/ $\mathrm{ZrO}_{2}$ Catalysts. Appl. Catal. A Gen. 2006, 297, 151-158. [CrossRef]

118. Zhang, L.; Meng, M.; Zhou, S.; Sun, Z.; Zhang, J.; Xie, Y.; Hu, T. Promotional Effect of Partial Substitution of Zn by Ce in CuZnAlO Catalysts Used for Hydrogen Production via Steam Reforming of Dimethyl Ether. J. Power Sources 2013, 232, 286-296. [CrossRef]

119. Mrad, M.; Hammoud, D.; Gennequin, C.; Aboukaïs, A.; Abi-Aad, E. A Comparative Study on the Effect of Zn Addition to Cu/Ce and $\mathrm{Cu} / \mathrm{Ce}-\mathrm{Al}$ Catalysts in the Steam Reforming of Methanol. Appl. Catal. A Gen. 2014, 471, 84-90. [CrossRef]

120. Hammoud, D.; Gennequin, C.; Aboukaïs, A.; Aad, E.A. Steam Reforming of Methanol over X\% Cu/Zn-Al 400500 Based Catalysts for Production of Hydrogen: Preparation by Adopting Memory Effect of Hydrotalcite and Behavior Evaluation. Int. J. Hydrogen Energy 2015, 40, 1283-1297. [CrossRef]

121. Shen, J.-P.; Song, C. Influence of Preparation Method on Performance of Cu/Zn-Based Catalysts for Low-Temperature Steam Reforming and Oxidative Steam Reforming of Methanol for $\mathrm{H}_{2}$ Production for Fuel Cells. Catal. Today 2002, 77, 89-98. [CrossRef]

122. Motevalian Seyedi, A.; Haghighi, M.; Rahemi, N. Significant Influence of Cutting-Edge Plasma Technology on Catalytic Properties and Performance of CuO-ZnO- $\mathrm{Al}_{2} \mathrm{O}_{3}-\mathrm{ZrO}_{2}$ Nanocatalyst Used in Methanol Steam Reforming for Fuel Cell Grade Hydrogen Production. Ceram. Int. 2017, 43, 6201-6213. [CrossRef]

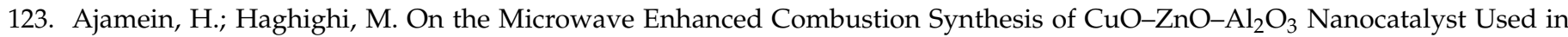
Methanol Steam Reforming for Fuel Cell Grade Hydrogen Production: Effect of Microwave Irradiation and Fuel Ratio. Energy Convers. Manag. 2016, 118, 231-242. [CrossRef] 


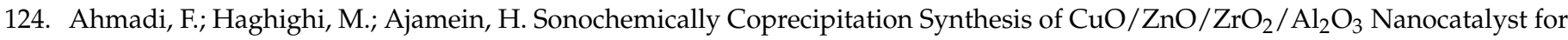
Fuel Cell Grade Hydrogen Production via Steam Methanol Reforming. J. Mol. Catal. A Chem. 2016, 421, 196-208. [CrossRef]

125. Sanches, S.G.; Flores, J.H.; de Avillez, R.R.; Pais da Silva, M.I. Influence of Preparation Methods and Zr and Y Promoters on $\mathrm{Cu} / \mathrm{ZnO}$ Catalysts Used for Methanol Steam Reforming. Int. J. Hydrogen Energy 2012, 37, 6572-6579. [CrossRef]

126. Bartoň, J.; Pour, V. Kinetics of Catalytic Conversion of Methanol at Higher Pressures. Collect. Czechoslov. Chem. Commun. 1980, 45, 3402-3407. [CrossRef]

127. Santacesaria, E.; Carrá, S. Kinetics of Catalytic Steam Reforming of Methanol in a Cstr Reactor. Appl. Catal. 1983, 5, 345-358. [CrossRef]

128. Amphlett, J.C.; Evans, M.J.; Mann, R.F.; Weir, R.D. Hydrogen Production by the Catalytic Steam Reforming of Methanol: Part 2: Kinetics of Methanol Decomposition Using Girdler G66B Catalyst. Can. J. Chem. Eng. 1985, 63, 605-611. [CrossRef]

129. Takahashi, K.; Takezawa, N.; Kobayashi, H. The Mechanism of Steam Reforming of Methanol over a Copper-Silica Catalyst. Appl. Catal. 1982, 2, 363-366. [CrossRef]

130. Jiang, C.J.; Trimm, D.L.; Wainwright, M.S.; Cant, N.W. Kinetic Study of Steam Reforming of Methanol over Copper-Based Catalysts. Appl. Catal. A Gen. 1993, 93, 245-255. [CrossRef]

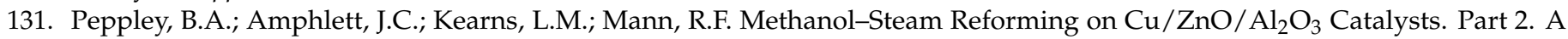
Comprehensive Kinetic Model. Appl. Catal. A Gen. 1999, 179, 31-49. [CrossRef]

132. Mastalir, A.; Frank, B.; Szizybalski, A.; Soerijanto, H.; Deshpande, A.; Niederberger, M.; Schomäcker, R.; Schlögl, R.; Ressler, T. Steam Reforming of Methanol over $\mathrm{Cu} / \mathrm{ZrO}_{2} / \mathrm{CeO}_{2}$ Catalysts: A Kinetic Study. J. Catal. 2005, 230, 464-475. [CrossRef]

133. Papavasiliou, J.; Avgouropoulos, G.; Ioannides, T. Steady-State Isotopic Transient Kinetic Analysis of Steam Reforming of Methanol over Cu-Based Catalysts. Appl. Catal. B Environ. 2009, 88, 490-496. [CrossRef]

134. Takezawa, N.; Iwasa, N. Steam Reforming and Dehydrogenation of Methanol: Difference in the Catalytic Functions of Copper and Group VIII Metals. Catal. Today 1997, 36, 45-56. [CrossRef]

135. Zhang, R.; Sun, Y.; Peng, S. In Situ FTIR Studies of Methanol Adsorption and Dehydrogenation over Cu/SiO 2 Catalyst. Fuel 2002, 81, 1619-1624. [CrossRef]

136. Xia, G.; Holladay, J.D.; Dagle, R.A.; Jones, E.O.; Wang, Y. Development of Highly Active Pd-ZnO/ $\mathrm{Al}_{2} \mathrm{O}_{3}$ Catalysts for Microscale Fuel Processor Applications. Chem. Eng. Technol. 2005, 28, 515-519. [CrossRef]

137. Iwasa, N.; Mayanagi, T.; Ogawa, N.; Sakata, K.; Takezawa, N. New Catalytic Functions of Pd-Zn, Pd-Ga, Pd-In, Pt-Zn, Pt-Ga and Pt-In Alloys in the Conversions of Methanol. Catal. Lett. 1998, 54, 119-123. [CrossRef]

138. Cai, F.; Ibrahim, J.J.; Fu, Y.; Kong, W.; Zhang, J.; Sun, Y. Low-Temperature Hydrogen Production from Methanol Steam Reforming on Zn-Modified Pt/MoC Catalysts. Appl. Catal. B Environ. 2020, 264, 118500. [CrossRef]

139. Barrios, C.E.; Bosco, M.V.; Baltanás, M.A.; Bonivardi, A.L. Hydrogen Production by Methanol Steam Reforming: Catalytic Performance of Supported-Pd on Zinc-Cerium Oxides' Nanocomposites. Appl. Catal. B Environ. 2015, 179, 262-275. [CrossRef]

140. Men, Y.; Yang, M. SMSI-like Behavior and Ni Promotion Effect on NiZnAl Catalysts in Steam Reforming of Methanol. Catal. Commun. 2012, 22, 68-73. [CrossRef]

141. Liu, Z.; Yao, S.; Johnston-Peck, A.; Xu, W.; Rodriguez, J.A.; Senanayake, S.D. Methanol Steam Reforming over Ni-CeO $2 \mathrm{Model}$ and Powder Catalysts: Pathways to High Stability and Selectivity for $\mathrm{H} 2 / \mathrm{CO}_{2}$ Production. Catal. Today 2018, 311, 74-80. [CrossRef]

142. Iwasa, N.; Kudo, S.; Takahashi, H.; Masuda, S.; Takezawa, N. Highly Selective Supported Pd Catalysts for Steam Reforming of Methanol. Catal. Lett. 1993, 19, 211-216. [CrossRef]

143. Iwasa, N.; Masuda, S.; Takezawa, N. Steam Reforming of Methanol over Ni, Co, Pd and Pt Supported on ZnO. React. Kinet. Catal. Lett. 1995, 2, 349-353. [CrossRef]

144. Iwasa, N.; Takezawa, N. New Supported Pd and Pt Alloy Catalysts for Steam Reforming and Dehydrogenation of Methanol. Top. Catal. 2003, 22, 215-224. [CrossRef]

145. Dagle, R.A.; Chin, Y.-H.; Wang, Y. The Effects of PdZn Crystallite Size on Methanol Steam Reforming. Top. Catal. 2007, 46, 358-362. [CrossRef]

146. Chin, Y.-H.; Wang, Y.; Dagle, R.A.; Shari Li, X. Methanol Steam Reforming over Pd/ZnO: Catalyst Preparation and Pretreatment Studies. Fuel Process. Technol. 2003, 83, 193-201. [CrossRef]

147. Ranganathan, E.S.; Bej, S.K.; Thompson, L.T. Methanol Steam Reforming over Pd/ZnO and Pd/CeO 2 Catalysts. Appl. Catal. A Gen. 2005, 289, 153-162. [CrossRef]

148. Conant, T.; Karim, A.M.; Lebarbier, V.; Wang, Y.; Girgsdies, F.; Schlögl, R.; Datye, A. Stability of Bimetallic Pd-Zn Catalysts for the Steam Reforming of Methanol. J. Catal. 2008, 257, 64-70. [CrossRef]

149. Avgouropoulos, G.; Papavasiliou, J.; Ioannides, T. Hydrogen Production from Methanol over Combustion-Synthesized Noble Metal/Ceria Catalysts. Chem. Eng. J. 2009, 154, 274-280. [CrossRef]

150. Kolb, G.; Keller, S.; Pecov, S.; Pennemann, H.; Zapf, R. Development of Microstructured Catalytic Wall Reactors for Hydrogen Production by Methanol Steam Reforming over Novel Pt/ $\mathrm{In}_{2} \mathrm{O}_{3} / \mathrm{Al}_{2} \mathrm{O}_{3}$ Catalysts. Chem. Eng. Trans. 2011, $24,133-138$.

151. Barbosa, R.L.; Papaefthimiou, V.; Law, Y.T.; Teschner, D.; Hävecker, M.; Knop-Gericke, A.; Zapf, R.; Kolb, G.; Schlögl, R.; Zafeiratos, S. Methanol Steam Reforming over Indium-Promoted $\mathrm{Pt} / \mathrm{Al}_{2} \mathrm{O}_{3}$ Catalyst: Nature of the Active Surface. J. Phys. Chem. C 2013, 117, 6143-6150. [CrossRef] 
152. Ma, Y.; Guan, G.; Shi, C.; Zhu, A.; Hao, X.; Wang, Z.; Kusakabe, K.; Abudula, A. Low-Temperature Steam Reforming of Methanol to Produce Hydrogen over Various Metal-Doped Molybdenum Carbide Catalysts. Int. J. Hydrogen Energy 2014, 39, 258-266. [CrossRef]

153. Lin, L.; Zhou, W.; Gao, R.; Yao, S.; Zhang, X.; Xu, W.; Zheng, S.; Jiang, Z.; Yu, Q.; Li, Y.-W.; et al. Low-Temperature Hydrogen Production from Water and Methanol Using Pt/ $\alpha$-MoC Catalysts. Nature 2017, 544, 80-83. [CrossRef] [PubMed]

154. Jacobs, G.; Davis, B.H. In Situ DRIFTS Investigation of the Steam Reforming of Methanol over Pt/Ceria. Appl. Catal. A Gen. 2005, 285, 43-49. [CrossRef]

155. Iwasa, N.; Mayanagi, T.; Nomura, W.; Arai, M.; Takezawa, N. Effect of Zn Addition to Supported Pd Catalysts in the Steam Reforming of Methanol. Appl. Catal. A Gen. 2003, 248, 153-160. [CrossRef]

156. Zhang, J.; Xie, Z.; Zhang, J.; Tang, Y.; Song, C.; Navessin, T.; Shi, Z.; Song, D.; Wang, H.; Wilkinson, D.P.; et al. High Temperature PEM Fuel Cells. J. Power Sources 2006, 160, 872-891. [CrossRef]

157. Avgouropoulos, G.; Papavasiliou, J.; Daletou, M.K.; Kallitsis, J.K.; Ioannides, T.; Neophytides, S. Reforming Methanol to Electricity in a High Temperature PEM Fuel Cell. Appl. Catal. B Environ. 2009, 90, 628-632. [CrossRef]

158. Özcan, O.; Akın, A.N. Thermodynamic Analysis of Methanol Steam Reforming to Produce Hydrogen for HT-PEMFC: An Optimization Study. Int. J. Hydrogen Energy 2019, 44, 14117-14126. [CrossRef]

159. Papavasiliou, J.; Słowik, G.; Avgouropoulos, G. Redox Behavior of a Copper-Based Methanol Reformer for Fuel Cell Applications. Energy Technol. 2018, 6, 1332-1341. [CrossRef]

160. Avgouropoulos, G.; Papavasiliou, J.; Ioannides, T.; Neophytides, S. Insights on the Effective Incorporation of a Foam-Based Methanol Reformer in a High Temperature Polymer Electrolyte Membrane Fuel Cell. J. Power Sources 2015, 296, 335-343. [CrossRef]

161. Avgouropoulos, G.; Paxinou, A.; Neophytides, S. In Situ Hydrogen Utilization in an Internal Reforming Methanol Fuel Cell. Int J. Hydrogen Energy 2014, 39, 18103-18108. [CrossRef]

162. Ribeirinha, P.; Alves, I.; Vázquez, F.V.; Schuller, G.; Boaventura, M.; Mendes, A. Heat Integration of Methanol Steam Reformer with a High-Temperature Polymeric Electrolyte Membrane Fuel Cell. Energy 2017, 120, 468-477. [CrossRef] 